\title{
Vertical distribution of herring larvae in relation to physical mixing and illumination
}

\author{
M. R. Heath, E. W. Henderson, D. L. Baird \\ Marine Laboratory, PO Box 101, Victoria Road, Aberdeen, United Kingdom
}

\begin{abstract}
Vertical distributions of 3 size groups of herring larvae Clupea harengus $\mathrm{L}$. in isothermal and stratified waters off the north coast of Scotland were recorded by repetitive sampling, adjacent to drifting markers, with an opening and closing high-speed plankton net. Concurrent measurements of light intensity at the sea surface, wind velocity and water column hydrography were related to the distributions of larvae by time series analysis. Results indicate that larvae in the size range 6 to $18 \mathrm{~mm}$ aggregated to form a layered distribution during the day but dispersed at night. However, the mean depth of the population was most strongly influenced by turbulence, especially wind-induced mixing. A predictive model of larval vertical distribution has been derived.
\end{abstract}

\section{INTRODUCTION}

The vertical distributions of fish larvae and other planktonic organisms in the sea have been extensively studied, and with recent improvements in opening and closing gear technology this has become an easier task. In the case of herring larvae, studies of vertical migration have been reported since the late 1950s (Bridger 1958, Wood 1971, Seliverstov 1974). However despite all the published work on this subject, there has apparently been no attempt to account quantitatively for variability in the vertical distribution in the open shelf seas in terms of measurements of physical variables all the descriptions in the literature have been of a qualitative nature. This is somewhat surprising since it is well known that both currents and the vertical distribution of food for fish larvae may also show distinct vertical stratification, so that the distribution of larvae through the water column is likely to have significant consequences for lateral advection and grazing rates, both of which have been extensively investigated. In contrast, there have been several analyses of vertical distributions of larvae in tidal estuarine regions (Fortier \& Leggett 1982, Graham \& Sampson 1982). In these areas, vertical migration through a vertical shear zone has been implicated as an adaptation to maintain horizontal position in estuaries (Fortier \& Leggett 1983).

Wood (1971) described some observations of the vertical distribution of autumn-spawned larvae off the north and west of Scotland. The main conclusions were that larvae were aggregated in the upper layers of the water in daylight, and more uniformly distributed at night. Large larvae $(>15 \mathrm{~mm})$ were closer to the surface during the day and deeper at night than smaller individuals.

Schnack (1972) described observations on vertical distribution of larvae on Aberdeen Bank (ca $56^{\circ} 25^{\prime} \mathrm{N}$, $\left.01^{\circ} 55^{\prime} \mathrm{W}\right)$ and concluded that small larvae $(<10 \mathrm{~mm})$ stayed higher in the water column than larger individuals during daylight. He found no obvious difference in the distribution of the small larvae between day and night, but the larger larvae tended to be more dispersed at night than in daylight. Bridger (1958) also found a trend for older larvae to be deeper by day. However, these descriptions were only qualitative, and no measurements of light intensity, or of any other physical parameters, were presented. Other reported observations of the vertical distribution of autumnspawned larvae since those made by Schnack have added little to this analysis. For example, Nichols et al. (1986) observed some downward extension of the distribution of larvae during night-time in isothermal water off Flamborough Head $\left(54^{\circ} 30^{\prime} \mathrm{N}, 00^{\circ} 01^{\prime} \mathrm{W}\right)$, but with no clear difference between size groups.

All of these studies were carried out in well-mixed, isothermal water columns. This is because autumnspawned larvae are mainly confined to tidally energetic mixed regions and fronts between mixed and stratified zones delineate the boundary of their distribution (Richardson et al. 1986). However, observa- 
tions on spring-spawned larvae have included studies carried out in stratified environments. Recently, Bjorke et al. (1986) described an investigation of the vertical distribution of Norwegian spring-spawned larvae adjacent to a drifting buoy at approximately $63^{\circ} 00^{\prime} \mathrm{N}, 06^{\circ}$ $00^{\prime} \mathrm{E}$ where there was considerable stratification of temperature and salinity. The highest concentrations of larvae were caught in the pycnocline which was at ca $60 \mathrm{~m}$. Sixty \% of the populations were located above this depth at all times, and only $20 \%$ were found below $70 \mathrm{~m}$. No clear vertical migration pattern was observed, but there appeared to be a downward extension of the distribution of all size groups at night. By contrast, Dragesund (1970) working in the same area, also on spring-spawned larvae, reported highest abundances in the upper $20 \mathrm{~m}$ by night, and between 20 and $40 \mathrm{~m}$ during daylight

In our investigations we have analysed the contribution of various physical parameters to variability in the vertical distribution of larval herring Clupea harengus $\mathrm{L}$. in the length range 6 to $18 \mathrm{~mm}$ sampled in isothermal and stratified water off the north of Scotland during September 1986. The data have been used to develop a simple model based on mixing and light intensity at the sea surface. Models of this type must form the basis for any assessment of the consequences of meteorological and hydrographic events for the advection and survival of fish larvae.

\section{MATERIALS AND METHODS}

Survey area and general procedure. Data were collected during investigations of the transport and biology of larval herring Clupea harengus L. off the Orkney Isles, carried out from FRV 'Scotia' between 6 and 13 September 1986 (Fig. 1). The procedure was as follows

A general survey of the area on 6 September located a patch of herring larvae with its centre at ca $59^{\circ} 00^{\prime} \mathrm{N}$, $04^{\circ} 00^{\prime} \mathrm{W}$. A buoy equipped with a flashing light and radar reflector, and attached to a sea anchor at a depth of $30 \mathrm{~m}$, was launched close to this position and provided a Lagrangian marker of the patch of Iarvae. Repeated sampling of physical and biological parameters was carried out adjacent to the buoy for $3 \mathrm{~d}$. The buoy was then recovered, the whole area resurveyed to map out the patch of larvae once again, and the sampling procedure repeated. Two such drift study periods were completed from 00:00 h GMT 7 Sep to 23:30 h GMT 9 Sep, and 00:00 h GMT 11 Sep to 00:30 h GMT $13 \mathrm{Sep}$.

Data collection. Biological data: Herring larvae and other planktonic organisms were sampled with a Gulf III high speed net (Gehringer 1952) towed at $5 \mathrm{kn}$. For general surveys to map the distribution of larvae a conventional sampler with a $19 \mathrm{~cm}$ nose-cone was used in a double oblique tow to within $5 \mathrm{~m}$ of the sea bed. Water flow through the sampler was recorded using a calibrated meter mounted in the nose-cone, and the numbers of larvae caught in each tow were used to calculate the number below $1 \mathrm{~m}^{2}$ of sea surface.

The vertical distribution of larvae during the drift survey periods was determined with a modified multiple opening and closing version of the standard Gulf sampler. This gear has been described by Dunn et al. (1985) and consists of a set of 4 nets within the body of a standard sampler, and an opening and closing device driven by a stepping motor. Control of the motor, monitoring of the location of the sampler and recording of flowmeter and temperature data during the tow were carried out by means of a through-water acoustic link. This gear has considerable advantages over the more familiar MOCNESS sampler (Wiebe et al. 1976) since the volume filtered can be more accurately measured, and the problem of avoidance by herring larvae, which can lead to very large day/night differences in catches by the MOCNESS (Brander et al. 1987), is minimised by the high towing speed of the modified Gulf III $(5 \mathrm{kn})$. The sampler was launched with all nets closed, and wire paid out until the sampler was ca $5 \mathrm{~m}$ above the sea bed. Each net was then opened sequentially, during the recovery phase, to sample obliquely 4 depth strata of approximately equal height covering the whole water column. The recovery rate of the wire was varied so that the duration of filtration by each net was ca 5 min (equivalent to a volume of ca $10 \mathrm{~m}^{3}$ ).

Immediately upon recovery of the sampler all herring larvae were removed from the catches of plankton and preserved in $4 \%$ buffered neutral saline formaldehyde, and stored in subdued light at room temperature. Between 2 and 4 mo after collection, all preserved larvae from the opening and closing net tows were measured to the nearest $0.1 \mathrm{~mm}$, and the number per $\mathrm{m}^{3}$ in each of 3 size groups calculated for each depth stratum in each tow This concentration was referred to the mid-depth of each stratum. No allowance for shrinkage due to preservation was made in the analysis of length data.

Physical data: Temperature and salinity profiles of the water column were recorded at ca $2 \mathrm{~h}$ intervals during the drift surveys by a CTD (NBA Controls Ltd Model TDS-7M) interfaced to a microcomputer. Calibration data were collected at approximately 6 h intervals with Knudsen reversing water bottles. Water depths were recorded with an echosounder which was operated continuously throughout the cruise.

Illumination incident at the sea surface was measured throughout the survey by a level response light sensor fitted with a cosine collector (Ramsden Scientific 
Fig. 1. Survey area and sea-bed topography off the north of Scotland. Stippled areas are shallower than $80 \mathrm{~m}$. Depth contours in $\mathrm{m}$. Inset shows the area in relation to the rest of Scotland, and a schematic representation of the main water circulation features

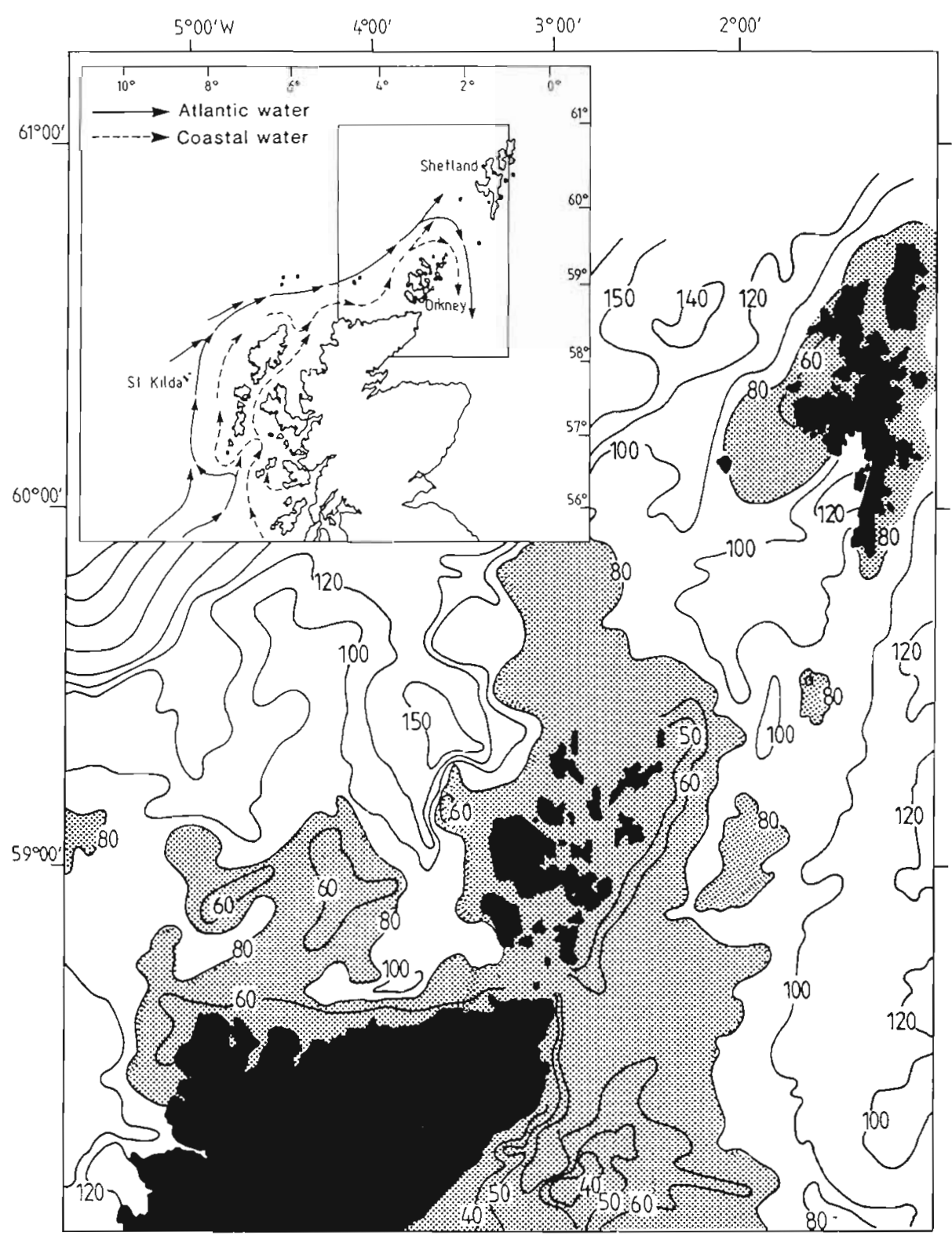

Inst.) mounted at the masthead and interfaced to the analog-digital converter of an Acorn BBC microcomputer. The system was calibrated in the laboratory against a standard light source, and the logging and display of data at $3 s$ intervals were controlled by software. The mean and standard deviation of intensities in $\mathrm{W} \mathrm{m}^{-2}$ over successive $5 \mathrm{~min}$ periods were calculated and recorded on disc.

The apparent wind speed and direction relative to the ship's head, and the vessel's speed and direction, were recorded at $2 \mathrm{~h}$ intervals throughout the cruise from a masthead-mounted anemometer, the ship's log, and the gyro-compass respectively. True wind speed and direction were subsequently calculated from these data.
The vessel attempted to retain visual contact with the marker buoy throughout each of the drift study periods, and the position of the buoy was recorded at 1 to $2 \mathrm{~h}$ intervals. Subsequently, the estimated position of the buoy was calculated at $1 \mathrm{~h}$ intervals throughout the drift period by linear interpolation where necessary. The mean velocity in each $1 \mathrm{~h}$ period was then calculated from these data.

Processing of raw data. Time: Each observation was referred to by the time (h) after the start of each drift survey period 100:00 h GMT on $7 \mathrm{Sep}$, and 00:00 $\mathrm{h}$ GMT on 11 Sep).

Light intensity: Raw data on sea-surface light intensity (mean over $5 \mathrm{~min}$ intervals) were averaged over $1 \mathrm{~h}$ periods for use in the analysis. Averaging was carried 
out for each $1 \mathrm{~h}$ interval throughout the day and centred on $30 \mathrm{~min}$ past the hour.

Stratification and mixed layer thickness: The stratification parameter ( $\phi$ ) was calculated from the density profile at each sampling position. This gives a measure of the mechanical work required to mix the water column, and was defined by Simpson (1981) as:

$$
\phi=g h \int_{-h}^{0}\left(p-p_{0}\right) z \cdot d z
$$

where $p=$ density at depth $z_{i} p_{0}=$ depth mean density; $h=$ total water depth; $g=$ acceleration due to gravity.

The thickness of the surface mixed layer was determined from the temperature profiles measured during each drift period. During the first period, the water column was isothermal, so the mixed layer thickness was taken to be equal to the water depth. During the second drift period there was a strong density gradient from the surface to the sea bed, but no well-defined pycnocline region. The depth of the base of the surface mixed layer was therefore taken to be the depth of the $11.2^{\circ} \mathrm{C}$ isotherm which corresponded approximately to the depth above which the temperature gradient was consistently zero or very small.

Measures of turbulence: Two measures of turbulence were calculated. First, a measure of the surface turbulence caused by wind-induced wave action was obtained by calculating the wind stress:

Wind stress $(\mathrm{Pa})=2.6 \times 10^{-3} \times$ air density $\times$ [wind speed $\left.\left(\mathrm{ms}^{-1}\right)\right]^{2}$ (McLellan 1965)

The value used for air density was $1.3 \mathrm{~kg} \mathrm{~m}^{-3}$

Secondly, a measure of turbulence induced by bottom friction was obtained from the cube of the current speed (Simpson \& Hunter 1974). The current speed at each sampling time was estimated from the rate of displacement of the marker buoy. Clearly, the movements of the buoy can only reflect currents at the drogue depth $(30 \mathrm{~m})$, but other studies carried out in this area (J. H. A. Martin pers. comm.) have found very little variation in tidal current speed over the middle two-thirds of the water column. Residual velocities (after removal of tidal vectors) may be variable, but these only represent a small component of the total water movements.

Vertical distributions of larvae: One would anticipate significant trends in the depth-integrated catches of larvae sampled over a time period whether sampling takes place at a fixed geographical location or at a position which is drifting with the water currents. Hence, the absolute concentrations of larvae (no. $\mathrm{m}^{-3}$ ) in various depth intervals down the water column cannot easily be related to the depth distribution of environmental or any other parameters. Two methods of rationalising the depth-integrated catch data were employed. In the first method, the mean depth or centre of density of the observed concentration distribution and an aggregation index were calculated for each size group caught in each tow. The aggregation index was the depth average percentage deviation from the mean concentration down the water column, i. e. the index equalled zero for a uniformly distributed population, and increased with the layering of the vertical distribution. This method characterised the vertical distributions in a concise manner, but the disadvantage was that the actual distribution of concentrations could not be reconstructed.

The second method of characterising the vertical distributions of larvae allowed the original distribution to be reconstructed. In this method, the depth distributions of the larvae in each size group were expressed as quartile depths - that is the depths above which 25,50, 75 and $100 \%$ of the total population were found (Fig. 2). The actual concentration distribution can be reconstructed from quartile depth information since a known fraction of the population resides in each interquartile depth interval.

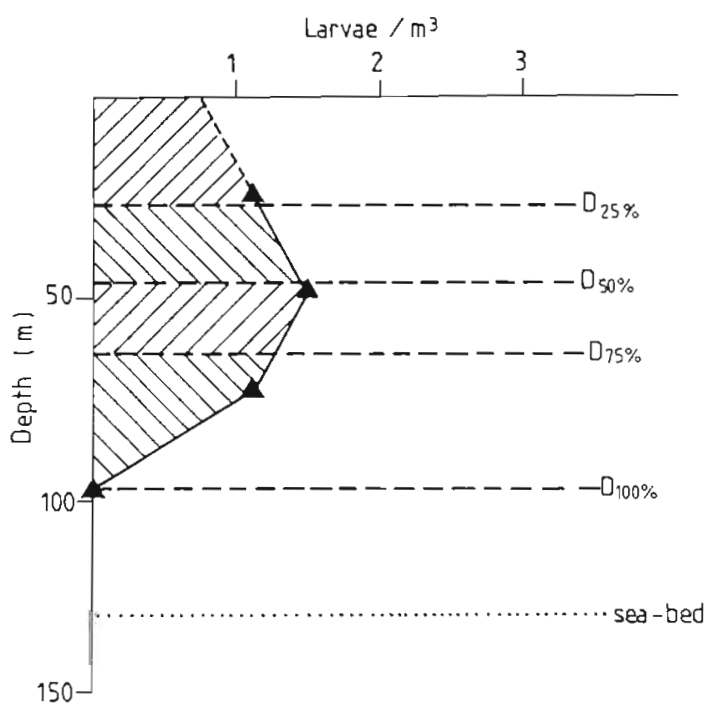

Fig 2. Diagramatic explanation of the quartile depths. $D_{x} \%$ refers to the depth above which $x \%$ of the total integrated population below $1 \mathrm{~m}^{2}$ is found. Consequently, each of the shaded areas contain $25 \%$ of the total population. In this example, which is based on real data, the total population is $103 \mathrm{~m}^{2}$

Data analysis. Auto- and cross-correlation analyses (Jenkins \& Watts 1968) were used to determine and compare the periodicity and phase differences of variations in the mean depth and aggregation of larvae, and in each of the environmental parameters during each drift period. Auto-correlation analysis requires that all data observations are present at regularly spaced time 
intervals throughout the record, and this condition was met only by the light, wind and current speed data. All data records were therefore interpolated to a time resolution of $1 \mathrm{~h}$ throughout each drift period and the analysis carried out on the interpolated data.

A simple predictive model of the vertical distribution of larvae was derived from the results of the auto-and cross-correlation analysis. Coefficients for this model were obtained by multiple regression of quartile depths of larvae against selected environmental variables.

\section{RESULTS}

The size range of larvae caught during the studies was ca 6 to $18 \mathrm{~mm}$ (total length), and the median length increased from ca $8 \mathrm{~mm}$ on 6 September to $10 \mathrm{~mm}$ on 13 September. The size groups used in the subsequent analysis of the data were 6.0 to $9.9 \mathrm{~mm} ; 10.0$ to $13.9 \mathrm{~mm}$ and $\geqslant 14.0 \mathrm{~mm}$.

The 2 time series of observations 7 to 9 Sep and 11 to $12 \mathrm{Sep}$ ) of surface light intensity, surface wind velocity, drifting buoy velocity, and vertical distributions of temperature, and no. $\mathrm{m}^{-3}$ of 3 size groups of herring larvae are shown in Figs. 3 and 4 . The 2 sets of observations were carried out on the same patch of larvae, but on different parts of the drift trajectory. During the first period ( 7 to 9 Sep) the patch was drifting in isothermal water, whilst by the second period (11 to $12 \mathrm{Sep}$ ) the larvae were within a boundary region separating mixed and stratified water (Fig. 5). In the stratified environment the larvae were almost entirely restricted to the surface mixed layer.

We were fortunate, in terms of the objectives of the investigations, to experience considerable variability in weather conditions during the experiments. Stormy and overcast conditions prevailed on 9 and 12 September, associated with the passage of low pressure weather systems to the north of the study area, relatively cloud-free but windy weather on 7 September and light winds on 11 September.

\section{General distribution of larvae}

Tables 1 and 2 show the depth-integrated concentrations of larvae (no. $\mathrm{m}^{-2}$ ), mean depths, aggregation indices and percentile depths for each of the 3 length categories caught at the sampling positions. The mean depths of each size group, averaged over each of the 2 sampling periods, did not differ significantly either within each period, or between periods, despite the differences in total water depth and stratification parameter between the 2 periods. However, there was a wide range of variation in mean depth within each period (Fig. 6).

The aggregation indices, averaged within each sampling period, were significantly higher for all length groups during the second period than during the first. This reflected the increased stratification of the water column since the larvae were restricted to the surface layers. There was some evidence of increasing aggregation with size during the first period (Fig.6).

\section{Auto- and cross-correlation analysis}

\section{Drift period 1}

The auto-correlation functions for the aggregation and mean depths of each size group of larvae are shown in Fig. 7. The functions for each of the environmental variables are shown in Fig. 8 . The functions for the distribution of the larvae show different characteristics for each size group. The aggregation of the small larvae and the mean depth of the medium sized larvae exhibited cyclic behaviour with frequencies which were approximately diel. The mean depth of the small larvae, the aggregation of the medium larvae, and both the distribution parameters for the large larvae showed a strong periodicity with a period in excess of $30 \mathrm{~h}$. The correlations between these auto-correlation functions of larval distribution, and the functions for each of the environmental variables are shown in Table 3. These results indicate that: (1) for the small larvae the mean depth varied with a frequency corresponding to that of the variation in wind stress, whilst the aggregation varied diurnally, i.e. with approximately the same frequency as the light intensity; (2) for the medium sized larvae the mean depth varied diurnally, but the variations in aggregation most closely paralleled those in the wind stress; (3) for the large larvae variations in both the mean depth and the aggregation were similar to those in the water depth. Current speed clearly had no significant influence on either the aggregation or the mean depth of the larvae.

The cross-correlation functions between the mean depth and aggregation, and the light, wind and water depth data are shown in Fig. 9. The wind stress showed the most consistent relationship with the mean depth data for each size group of larvae. In each case the highest positive correlation coefficient occurred at a lag of $\mathrm{ca}-2 \mathrm{~h}$ on the wind. Although the auto-correlations of the sounding and the mean depth of the large larvae were very similar, the cross-correlation showed them to be completely out of phase. The cross-correlation of the mean depth of the medium sized larvae and the light intensity indicated a strong phototactic response, that is, a movement towards the surface during light condi- 


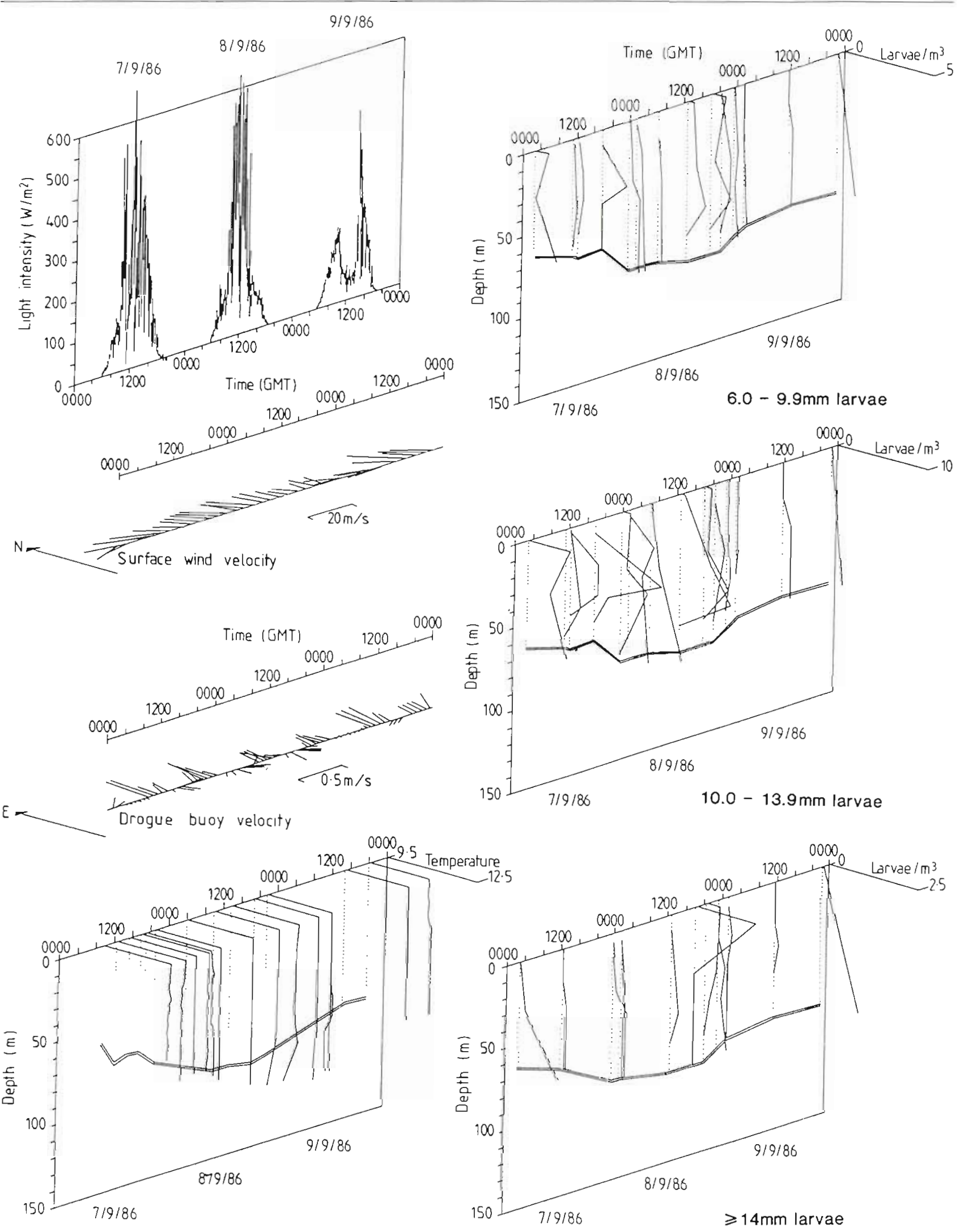

Fig. 3. Clupea harengus. Raw data on the vertical distributions of each size group of herring larvae and water temperatures, and other environmental parameters, collected during the first drift survey period ( 7 to 9 Sep 1986). Wind velocities are drawn as the directions from which the wind was blowing 

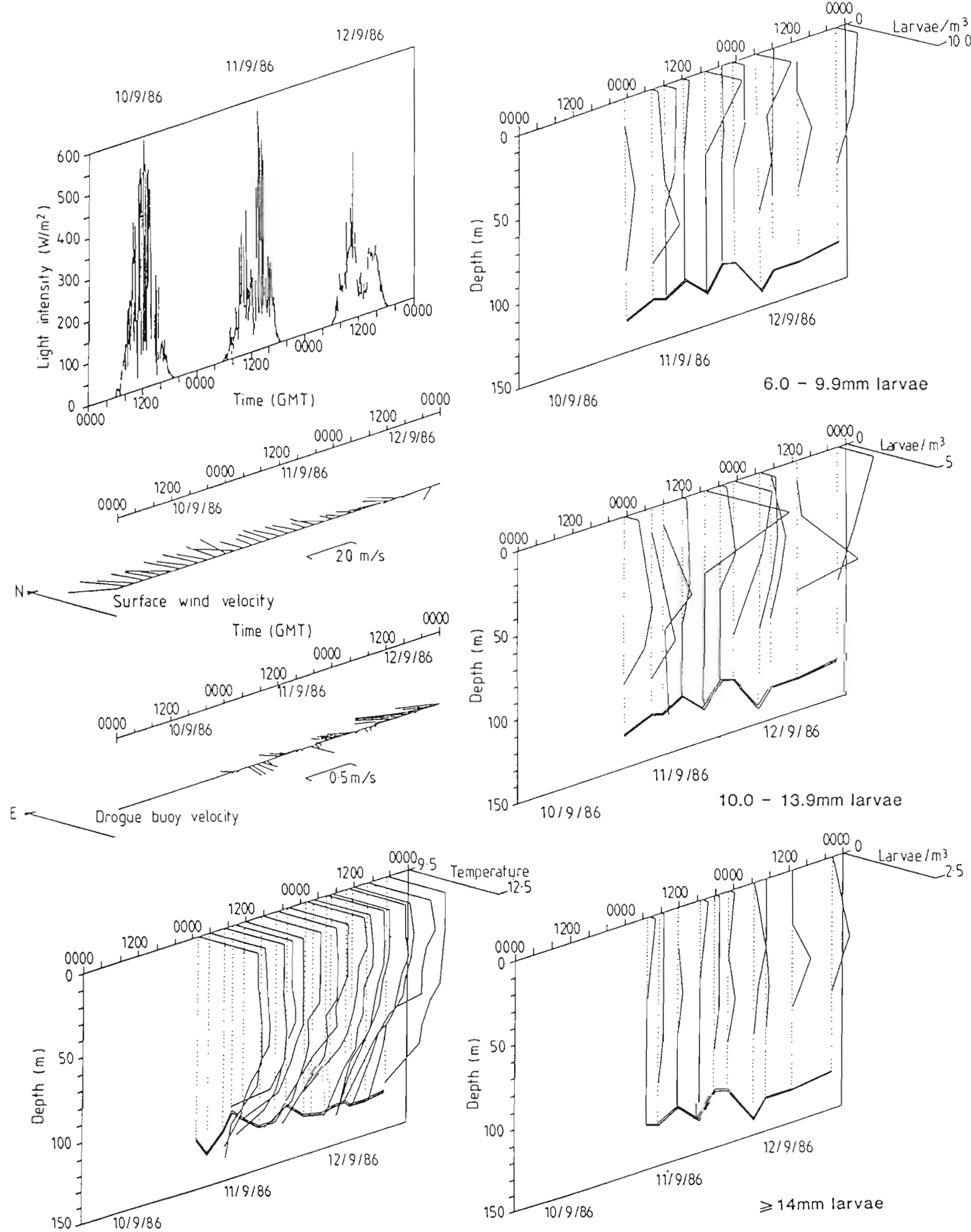

Fig. 4. Clupea harengus. Raw data on the vertical distributions of each size group of herring larvae and water temperatures, and other environmental parameters, collected during the second drift survey period (11 to 12 Sep 1986 ). Wind velocities are drawn as the directions from which the wind was blowing 

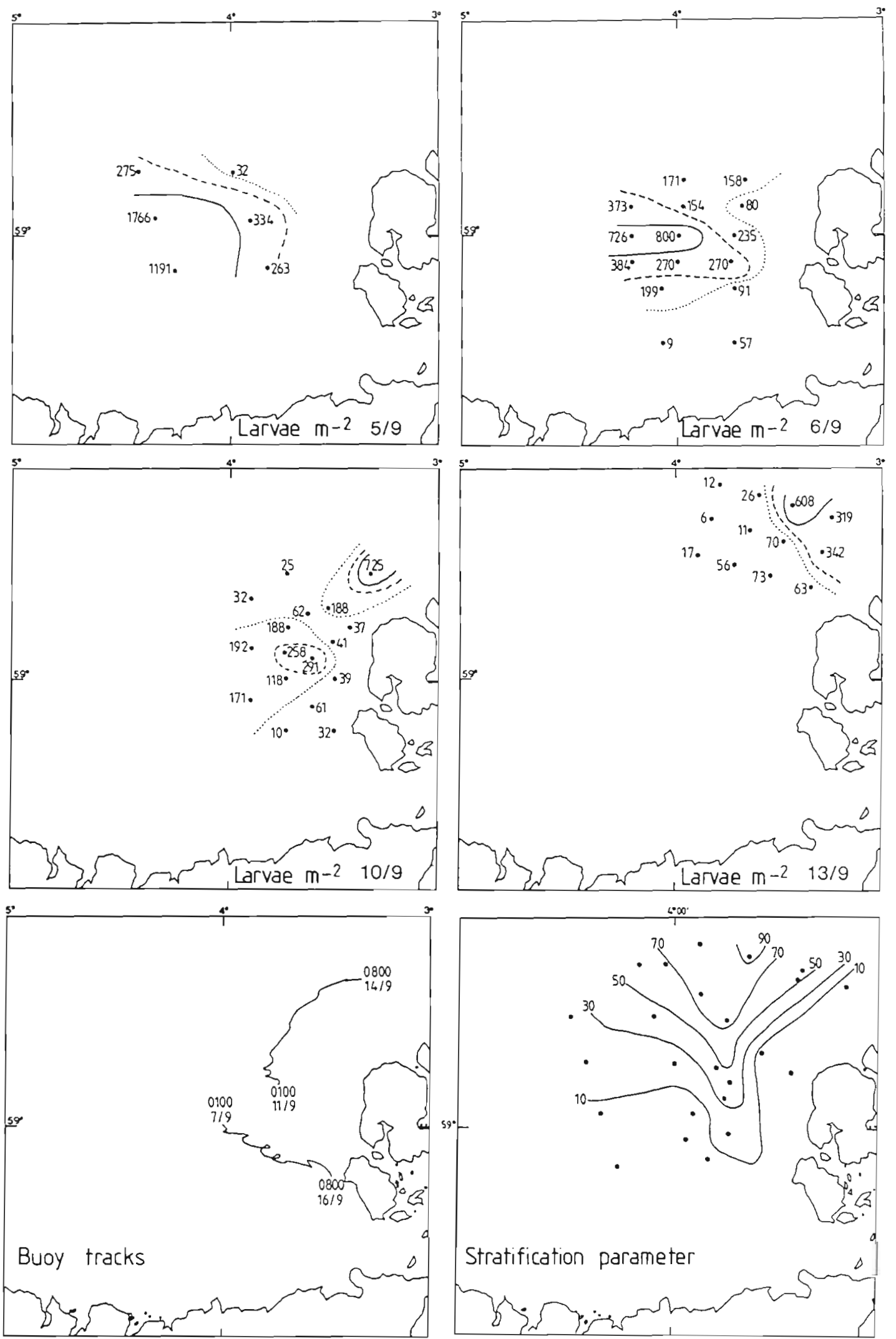

Fig. 5. Clupea harengus. Geographical distributions of herring larvae (numbers below $1 \mathrm{~m}^{2}$ sea surface) on $5,6,10$ and 13 September, trajectories of drifting buoys, and stratification parameter data accumulated from all surveys. Data on herring larvae relates to all sizes 
Table 1. Clupea harengas. Tabulated values of the depth-integrated number of larvae $\mathrm{m}^{-2}$, depth of the centre of density, aggregation index and quartile depths for each size group of larvae at each sampling position during the first drift survey period. Size groups: $\mathrm{S}, 6.0-9.9 \mathrm{~mm} ; \mathrm{M}, 10.0-13.9 \mathrm{~mm} ; \mathrm{L}_{1} \geqslant 14.0 \mathrm{~mm}$

\begin{tabular}{|c|c|c|c|c|c|c|c|c|c|}
\hline $\begin{array}{l}\text { Date } \\
1986\end{array}$ & $\begin{array}{c}\text { Time } \\
\text { (h) }\end{array}$ & $\begin{array}{l}\text { Size } \\
\text { group }\end{array}$ & $\begin{array}{l}\text { No. } \\
\mathrm{m}^{-2}\end{array}$ & $\begin{array}{c}\text { Centre of } \\
\text { density depth }\end{array}$ & $\begin{array}{l}\text { Aggregation } \\
\text { index }\end{array}$ & $D_{25 \%}$ & $\mathrm{D}_{50 \%}$ & $\mathrm{D}_{75 \%}$ & $\mathrm{D}_{100 \%}$ \\
\hline 07 Sep & $03: 00$ & $\begin{array}{l}S \\
M \\
L\end{array}$ & $\begin{array}{r}220 \\
32 \\
24\end{array}$ & $\begin{array}{l}32.0 \\
38.1 \\
48.0\end{array}$ & $\begin{array}{l}0.15 \\
0.48 \\
0.78\end{array}$ & $\begin{array}{l}13 \\
15 \\
41\end{array}$ & $\begin{array}{l}32 \\
46 \\
51\end{array}$ & $\begin{array}{l}50 \\
57 \\
58\end{array}$ & $\begin{array}{l}64 \\
64 \\
64\end{array}$ \\
\hline $07 \mathrm{Sep}$ & $11: 18$ & $\begin{array}{l}S \\
M \\
L\end{array}$ & $\begin{array}{r}65 \\
6 \\
0\end{array}$ & $\begin{array}{c}32.9 \\
40.3 \\
-\end{array}$ & $\begin{array}{c}0.44 \\
0.75 \\
-\end{array}$ & $\begin{array}{c}21 \\
32 \\
-\end{array}$ & $\begin{array}{c}35 \\
41 \\
-\end{array}$ & $\begin{array}{c}45 \\
49 \\
-\end{array}$ & $\begin{array}{c}65 \\
65 \\
-\end{array}$ \\
\hline 07 Sep & $12: 30$ & $\begin{array}{l}S \\
M \\
L\end{array}$ & $\begin{array}{r}99 \\
8 \\
4\end{array}$ & $\begin{array}{l}28.1 \\
32.0 \\
50.8\end{array}$ & $\begin{array}{l}0.87 \\
0.77 \\
0.68\end{array}$ & $\begin{array}{l}20 \\
23 \\
40\end{array}$ & $\begin{array}{l}28 \\
32 \\
51\end{array}$ & $\begin{array}{l}36 \\
41 \\
63\end{array}$ & $\begin{array}{l}53 \\
59 \\
73\end{array}$ \\
\hline $07 \mathrm{Sep}$ & $17: 55$ & $\begin{array}{l}S \\
M \\
L\end{array}$ & $\begin{array}{r}154 \\
24 \\
0\end{array}$ & $\begin{array}{c}30.3 \\
28.3 \\
-\end{array}$ & $\begin{array}{c}0.95 \\
1.15 \\
-\end{array}$ & $\begin{array}{c}24 \\
23 \\
-\end{array}$ & $\begin{array}{l}30 \\
29 \\
-\end{array}$ & $\begin{array}{c}36 \\
34 \\
-\end{array}$ & $\begin{array}{l}60 \\
44 \\
-\end{array}$ \\
\hline $07 \mathrm{Sep}$ & $23: 51$ & $\begin{array}{l}\mathrm{S} \\
\mathrm{M} \\
\mathrm{L}\end{array}$ & $\begin{array}{r}102 \\
38 \\
22\end{array}$ & $\begin{array}{l}44.4 \\
58.1 \\
61.4\end{array}$ & $\begin{array}{l}0.54 \\
0.53 \\
0.63\end{array}$ & $\begin{array}{l}32 \\
45 \\
48\end{array}$ & $\begin{array}{l}48 \\
60 \\
63\end{array}$ & $\begin{array}{l}59 \\
75 \\
77\end{array}$ & $\begin{array}{l}85 \\
90 \\
90\end{array}$ \\
\hline 08 Sep & $01: 36$ & $\begin{array}{l}S \\
M \\
L\end{array}$ & $\begin{array}{r}155 \\
27 \\
9\end{array}$ & $\begin{array}{l}50.0 \\
56.7 \\
56.1\end{array}$ & $\begin{array}{l}0.26 \\
0.37 \\
0.39\end{array}$ & $\begin{array}{l}27 \\
39 \\
39\end{array}$ & $\begin{array}{l}50 \\
59 \\
57\end{array}$ & $\begin{array}{l}72 \\
76 \\
74\end{array}$ & $\begin{array}{l}90 \\
90 \\
90\end{array}$ \\
\hline $08 \mathrm{Sep}$ & $06: 26$ & $\begin{array}{l}\mathrm{S} \\
\mathrm{M} \\
\mathrm{L}\end{array}$ & $\begin{array}{r}134 \\
13 \\
0\end{array}$ & $\begin{array}{c}64.9 \\
62.7 \\
-\end{array}$ & $\begin{array}{c}0.66 \\
0.60 \\
-\end{array}$ & $\begin{array}{c}53 \\
48 \\
-\end{array}$ & $\begin{array}{l}69 \\
64 \\
-\end{array}$ & $\begin{array}{c}81 \\
79 \\
-\end{array}$ & $\begin{array}{c}91 \\
91 \\
-\end{array}$ \\
\hline $08 \mathrm{Sep}$ & $12: 56$ & $\begin{array}{l}S \\
M \\
L\end{array}$ & $\begin{array}{r}220 \\
42 \\
8\end{array}$ & $\begin{array}{l}46.2 \\
42.6 \\
49.1\end{array}$ & $\begin{array}{l}0.65 \\
0.49 \\
0.78\end{array}$ & $\begin{array}{l}34 \\
27 \\
38\end{array}$ & $\begin{array}{l}49 \\
47 \\
51\end{array}$ & $\begin{array}{l}60 \\
59 \\
61\end{array}$ & $\begin{array}{l}80 \\
79 \\
79\end{array}$ \\
\hline 08 Sep & $18: 06$ & $\begin{array}{l}S \\
M \\
L\end{array}$ & $\begin{array}{l}86 \\
47 \\
34\end{array}$ & $\begin{array}{l}47.3 \\
40.1 \\
13.0\end{array}$ & $\begin{array}{l}0.66 \\
0.52 \\
1.25\end{array}$ & $\begin{array}{r}33 \\
17 \\
5\end{array}$ & $\begin{array}{l}54 \\
47 \\
11\end{array}$ & $\begin{array}{l}63 \\
61 \\
20\end{array}$ & $\begin{array}{l}80 \\
81 \\
39\end{array}$ \\
\hline 08 Sep & $20: 28$ & $\begin{array}{l}S \\
M \\
L\end{array}$ & $\begin{array}{l}41 \\
26 \\
19\end{array}$ & $\begin{array}{l}45.1 \\
46.8 \\
28.0\end{array}$ & $\begin{array}{l}0.78 \\
0.66 \\
0.69\end{array}$ & $\begin{array}{l}34 \\
34 \\
13\end{array}$ & $\begin{array}{l}44 \\
47 \\
26\end{array}$ & $\begin{array}{l}56 \\
60 \\
41\end{array}$ & $\begin{array}{l}83 \\
84 \\
79\end{array}$ \\
\hline 08 Sep & $23: 15$ & $\begin{array}{l}S \\
M \\
L\end{array}$ & $\begin{array}{l}18 \\
13 \\
10\end{array}$ & $\begin{array}{l}40.4 \\
54.0 \\
61.0\end{array}$ & $\begin{array}{l}0.34 \\
0.34 \\
0.58\end{array}$ & $\begin{array}{l}22 \\
35 \\
43\end{array}$ & $\begin{array}{l}44 \\
53 \\
62\end{array}$ & $\begin{array}{l}59 \\
76 \\
79\end{array}$ & $\begin{array}{l}79 \\
90 \\
90\end{array}$ \\
\hline 09 Sept & $01: 25$ & $\begin{array}{l}S \\
M \\
L\end{array}$ & $\begin{array}{r}10 \\
6 \\
2\end{array}$ & $\begin{array}{l}26.1 \\
71.0 \\
23.3\end{array}$ & $\begin{array}{l}0.74 \\
1.07 \\
1.32\end{array}$ & $\begin{array}{l}14 \\
63 \\
19\end{array}$ & $\begin{array}{l}26 \\
73 \\
23\end{array}$ & $\begin{array}{l}38 \\
80 \\
28\end{array}$ & $\begin{array}{l}59 \\
86 \\
39\end{array}$ \\
\hline 09 Sep & $11: 45$ & $\begin{array}{l}\mathrm{S} \\
\mathrm{M} \\
\mathrm{L}\end{array}$ & $\begin{array}{r}47 \\
9 \\
2\end{array}$ & $\begin{array}{l}56.2 \\
54.7 \\
38.3\end{array}$ & $\begin{array}{l}0.67 \\
0.66 \\
1.29\end{array}$ & $\begin{array}{l}43 \\
42 \\
34\end{array}$ & $\begin{array}{l}56 \\
54 \\
38\end{array}$ & $\begin{array}{l}69 \\
68 \\
43\end{array}$ & $\begin{array}{l}82 \\
82 \\
54\end{array}$ \\
\hline 09 Sep & $22: 30$ & $\begin{array}{l}\mathrm{S} \\
\mathrm{M} \\
\mathrm{L}\end{array}$ & $\begin{array}{l}66 \\
44 \\
44\end{array}$ & $\begin{array}{l}53.3 \\
55.0 \\
55.0\end{array}$ & $\begin{array}{l}0.42 \\
0.48 \\
0.48\end{array}$ & $\begin{array}{l}38 \\
41 \\
41\end{array}$ & $\begin{array}{l}57 \\
58 \\
58\end{array}$ & $\begin{array}{l}71 \\
72 \\
72\end{array}$ & $\begin{array}{l}83 \\
83 \\
83\end{array}$ \\
\hline
\end{tabular}

tions. However, there was no evidence for this in the other size groups. With regard to the aggregation of the larvae, the cross-correlation analysis indicated a strong tendency for the small larvae to group or aggregate with respect to one another during light conditions. We refer to this response as 'photo-aggregation'. There was only weak evidence for this in the larger size groups. The wind stress over the previous 2 to $6 \mathrm{~h}$ and the water depth were both inversely related to the aggregation of all size groups.

In conclusion, wind stress and water depth were the most important factors affecting the vertical distribu- 
Table 2. Clupea harengas. Tabulated values of the depth-integrated number of larvae $\mathrm{m}^{-2}$, depth of the centre of density, aggregation index and quartile depths for each size group of larvae at each sampling position during the second drift survey period. Size groups: $\mathrm{S}, 6.0-9.9 \mathrm{~mm} ; \mathrm{M}, 10.0-13.9 \mathrm{~mm} ; \mathrm{L}, \geqslant 14.0 \mathrm{~mm}$

\begin{tabular}{|c|c|c|c|c|c|c|c|c|c|}
\hline $\begin{array}{l}\text { Date } \\
1986\end{array}$ & $\begin{array}{l}\text { Time } \\
(\mathrm{h})\end{array}$ & $\begin{array}{l}\text { Size } \\
\text { group }\end{array}$ & $\begin{array}{l}\text { No. } \\
m^{-2}\end{array}$ & $\begin{array}{c}\text { Centre of } \\
\text { density depth }\end{array}$ & $\begin{array}{l}\text { Aggregation } \\
\text { index }\end{array}$ & $D_{25 \%}$ & $\mathrm{D}_{50 \%}$ & $\mathrm{D}_{75 \%}$ & $D_{100 \%}$ \\
\hline $10 \mathrm{Sep}$ & $23: 26$ & $\begin{array}{l}\mathrm{S} \\
\mathrm{M} \\
\mathrm{L}\end{array}$ & $\begin{array}{r}43 \\
103 \\
0\end{array}$ & $\begin{array}{c}57.3 \\
45.9 \\
-\end{array}$ & $\begin{array}{c}0.94 \\
0.60 \\
-\end{array}$ & $\begin{array}{c}45 \\
27 \\
-\end{array}$ & $\begin{array}{c}56 \\
47 \\
-\end{array}$ & $\begin{array}{l}70 \\
65 \\
-\end{array}$ & $\begin{array}{c}99 \\
99 \\
-\end{array}$ \\
\hline $11 \mathrm{Sep}$ & $05: 24$ & $\begin{array}{l}\mathrm{S} \\
\mathrm{M} \\
\mathrm{L}\end{array}$ & $\begin{array}{r}134 \\
55 \\
5\end{array}$ & $\begin{array}{l}57.2 \\
64.6 \\
16.3\end{array}$ & $\begin{array}{l}0.57 \\
0.85 \\
1.27\end{array}$ & $\begin{array}{r}39 \\
52 \\
6\end{array}$ & $\begin{array}{l}63 \\
67 \\
14\end{array}$ & $\begin{array}{l}77 \\
78 \\
25\end{array}$ & $\begin{array}{r}101 \\
101 \\
49\end{array}$ \\
\hline $11 \mathrm{Sep}$ & $08: 01$ & $\begin{array}{l}S \\
M \\
L\end{array}$ & $\begin{array}{r}70 \\
60 \\
9\end{array}$ & $\begin{array}{l}30.3 \\
56.5 \\
43.9\end{array}$ & $\begin{array}{l}0.91 \\
0.79 \\
0.54\end{array}$ & $\begin{array}{l}14 \\
39 \\
22\end{array}$ & $\begin{array}{l}29 \\
51 \\
44\end{array}$ & $\begin{array}{l}45 \\
64 \\
66\end{array}$ & $\begin{array}{r}74 \\
125 \\
99\end{array}$ \\
\hline $11 \mathrm{Sep}$ & $12: 13$ & $\begin{array}{l}\mathrm{S} \\
\mathrm{M} \\
\mathrm{L}\end{array}$ & $\begin{array}{r}16 \\
21 \\
3\end{array}$ & $\begin{array}{l}16.3 \\
35.2 \\
50.0\end{array}$ & $\begin{array}{l}1.24 \\
0.82 \\
1.25\end{array}$ & $\begin{array}{r}6 \\
20 \\
43\end{array}$ & $\begin{array}{l}14 \\
36 \\
50\end{array}$ & $\begin{array}{l}25 \\
50 \\
57\end{array}$ & $\begin{array}{l}49 \\
74 \\
74\end{array}$ \\
\hline 11 Sep & $17: 00$ & $\begin{array}{l}S \\
M \\
L\end{array}$ & $\begin{array}{r}100 \\
116 \\
5\end{array}$ & $\begin{array}{l}16.3 \\
16.3 \\
16.3\end{array}$ & $\begin{array}{l}1.30 \\
1.30 \\
1.30\end{array}$ & $\begin{array}{l}6 \\
6 \\
6\end{array}$ & $\begin{array}{l}14 \\
14 \\
14\end{array}$ & $\begin{array}{l}25 \\
25 \\
25\end{array}$ & $\begin{array}{l}49 \\
49 \\
49\end{array}$ \\
\hline $11 \mathrm{Sep}$ & $20: 20$ & $\begin{array}{l}\mathrm{S} \\
\mathrm{M} \\
\mathrm{L}\end{array}$ & $\begin{array}{r}12 \\
32 \\
7\end{array}$ & $\begin{array}{l}27.7 \\
29.1 \\
37.6\end{array}$ & $\begin{array}{l}1.00 \\
0.99 \\
0.63\end{array}$ & $\begin{array}{l}15 \\
18 \\
18\end{array}$ & $\begin{array}{l}28 \\
30 \\
37\end{array}$ & $\begin{array}{l}39 \\
40 \\
57\end{array}$ & $\begin{array}{l}62 \\
62 \\
87\end{array}$ \\
\hline $11 \mathrm{Sep}$ & $23: 13$ & $\begin{array}{l}\mathrm{S} \\
\mathrm{M} \\
\mathrm{L}\end{array}$ & $\begin{array}{r}67 \\
110 \\
7\end{array}$ & $\begin{array}{l}26.3 \\
31.8 \\
43.1\end{array}$ & $\begin{array}{l}0.98 \\
0.73 \\
0.80\end{array}$ & $\begin{array}{l}12 \\
14 \\
15\end{array}$ & $\begin{array}{l}25 \\
29 \\
53\end{array}$ & $\begin{array}{l}39 \\
47 \\
65\end{array}$ & $\begin{array}{l}86 \\
90 \\
87\end{array}$ \\
\hline $12 \mathrm{Sep}$ & $05: 00$ & $\begin{array}{l}S \\
M \\
L\end{array}$ & $\begin{array}{r}117 \\
64 \\
11\end{array}$ & $\begin{array}{l}28.7 \\
36.4 \\
39.2\end{array}$ & $\begin{array}{l}0.88 \\
0.84 \\
0.98\end{array}$ & $\begin{array}{r}9 \\
18 \\
27\end{array}$ & $\begin{array}{l}21 \\
35 \\
38\end{array}$ & $\begin{array}{l}48 \\
53 \\
51\end{array}$ & $\begin{array}{l}89 \\
91 \\
87\end{array}$ \\
\hline $12 \mathrm{Sep}$ & $07: 30$ & $\begin{array}{l}\mathrm{S} \\
\mathrm{M} \\
\mathrm{L}\end{array}$ & $\begin{array}{r}10 \\
34 \\
2\end{array}$ & $\begin{array}{l}30.1 \\
44.2 \\
62.5\end{array}$ & $\begin{array}{l}0.81 \\
0.92 \\
1.31\end{array}$ & $\begin{array}{l}11 \\
31 \\
55\end{array}$ & $\begin{array}{l}25 \\
43 \\
63\end{array}$ & $\begin{array}{l}48 \\
57 \\
70\end{array}$ & $\begin{array}{l}87 \\
87 \\
87\end{array}$ \\
\hline $12 \mathrm{Sep}$ & $13: 15$ & $\begin{array}{l}S \\
M \\
L\end{array}$ & $\begin{array}{l}41 \\
78 \\
12\end{array}$ & $\begin{array}{l}55.3 \\
52.5 \\
54.4\end{array}$ & $\begin{array}{l}1.20 \\
1.30 \\
1.33\end{array}$ & $\begin{array}{l}47 \\
46 \\
47\end{array}$ & $\begin{array}{l}54 \\
52 \\
54\end{array}$ & $\begin{array}{l}64 \\
60 \\
62\end{array}$ & $\begin{array}{l}86 \\
78 \\
80\end{array}$ \\
\hline $12 \mathrm{Sep}$ & $22: 11$ & $\begin{array}{l}\mathrm{S} \\
\mathrm{M} \\
\mathrm{I}\end{array}$ & $\begin{array}{r}115 \\
79 \\
17\end{array}$ & $\begin{array}{l}29.7 \\
26.5 \\
41.8\end{array}$ & $\begin{array}{l}0.90 \\
0.94 \\
0.97\end{array}$ & $\begin{array}{l}13 \\
10 \\
31\end{array}$ & $\begin{array}{l}28 \\
23 \\
43\end{array}$ & $\begin{array}{l}44 \\
40 \\
53\end{array}$ & $\begin{array}{l}78 \\
78 \\
78\end{array}$ \\
\hline
\end{tabular}

tion of larvae during the first drift survey, with some evidence of photo-aggregation and phototaxis amongst the smali and medium sized larvae. The distribution of the large larvae was least well explained by the variables measured in this study.

\section{Drift period 2}

The auto-correlation functions for the larval distribution and environmental data corresponding to the second drift period, are shown in Figs. 10 and 11. In this case there was more consistency in the behaviour of the 3 size groups of larvae. The aggregation of each size group exhibited a strong periodicity with a period of ca $24 \mathrm{~h}$, whilst the mean depth of the small and medium sized larvae varied with a frequency of more than $30 \mathrm{~h}$. The mean depth of the large larvae showed complex variations which were not well described by a single frequency. The correlations between the autocorrelation functions for the larval distribution data and each of the environmental parameters are shown in Table 4. These results indicate that: (1) the aggregation of all size groups was closely related to the seasurface light intensity; (2) the mean depth auto-correlation functions of all size groups of larvae were significantly correlated with all the auto-correlations of the physical variables except the light intensity. However, the current speed auto-correlation showed no significant periodicity and was disregarded in assess- 

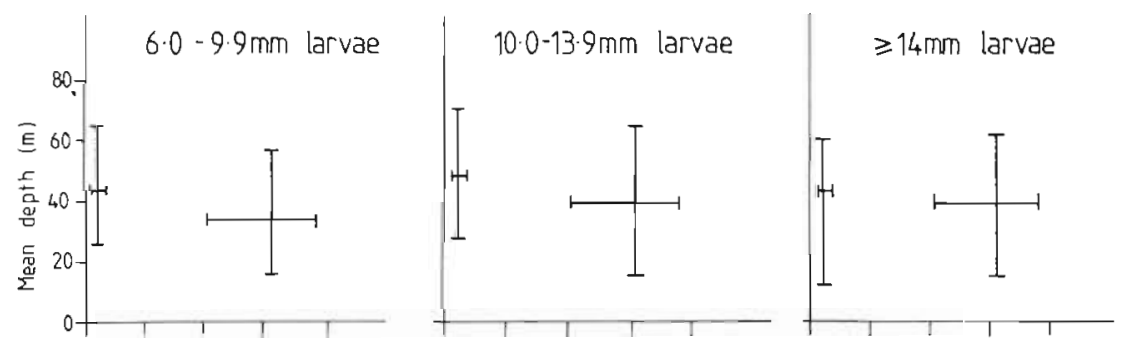

Fig. 6. Clupea harengus. Range of variations in the depth of the centre of density (mean depth) and aggregation of each size group of larvae, and water column stratification during each drift survey. Range bars represent the full range of values encountered around the mean for each parameter. Data from the more stratified environment relates to the second drift survey
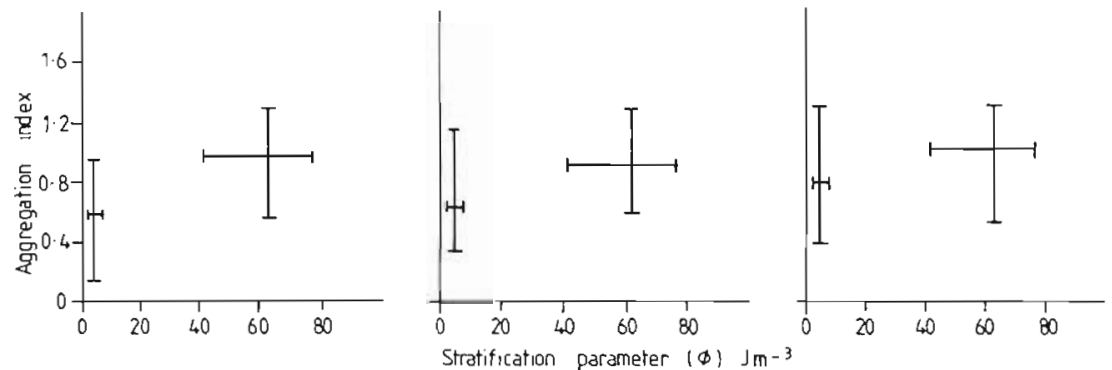

ing the origin of the periodicity in the mean depth data. The remaining 3 variables (wind stress, mixed layer thickness, and water depth) should be interrelated, and since the larvae were restricted to the surface layer it seemed reasonable to disregard the water depth as having a direct effect on the mean depth of the larvae.

The cross-correlation functions between the aggregation and light intensity, and between the mean depth of the larvae, and the light intensity, wind stress and mixed layer thickness are shown in Fig. 12. These data clearly show strong photoaggregation by all size groups of larvae, with a lag of $c a-2 h$ on the light intensity. Variations in the mean depth of all size groups were in phase with the mixing depth variations, but completely out of phase with the wind stress. This is accounted for by a lag between the cross-correlations of wind stress and mixed layer thickness (Fig. 13). However, the lag implies that variation in the mixed layer preceded variations in wind stress by ca $3 \mathrm{~h}$, which is inconceivable. We must therefore conclude that the mixed layer thickness is not a direct consequence of the wind stress in this case, but influenced in the first instance by some other factors which may be a consequence of the fact that the survey was Lagrangian (i. e. carried out at a drifting position rather than at a fixed Eulerian position).

In conclusion, all sizes of larvae in Drift Survey 2 showed strong photo-aggregation. However, the mean depth of all size groups was primarily determined by the thickness of the surface mixed layer, which was correlated with the variations in wind stress, but in this instance not necessarily causally related.

\section{Modelling the vertical distribution}

Coefficients for a simple predictive model of the vertical distribution of herring larvae were obtained by multiple regression. The analysis was performed using the percentile depths of the larvae as dependent ( $y$ ) variables so that an actual depth profile could be reconstructed from the results. The environmental parameters selected as independent $(x$ ) variables were those which had shown most prominence in the auto- and cross-correlation analysis, and which were uncorrelated amongst themselves - namely surface light intensity, wind stress and water depth in environments with stratification parameters less than 10 (approximately the maximum value during Drift Survey 1), and light intensity and mixed layer thickness in environments with stratification parameters greater than 10

The regression analysis was carried out on the original observations of quartile depths, not on time-interpolated data. The light intensity values used were those $2 \mathrm{~h}$ previous to the sampling times, and where wind stress was included, the values were those $2 \mathrm{~h}$ prior to sampling of the larvae.

Results of the multiple regressions, in the form of 2 sets of 4 quartile-depth predictive equations for each size group of larvae, are shown in Tables 5 and 6 . The percentage of variance accounted for by the regressions was greatest for the $10.0-13.9 \mathrm{~mm}$ size group of larvae, and least for the large larvae (> $14 \mathrm{~mm}$ ), in both the mixed and stratified environments. An actual profile of herring larvae concentration can be derived from the quartile depths and a value for the depth-integrated population numbers, since a known fraction of 


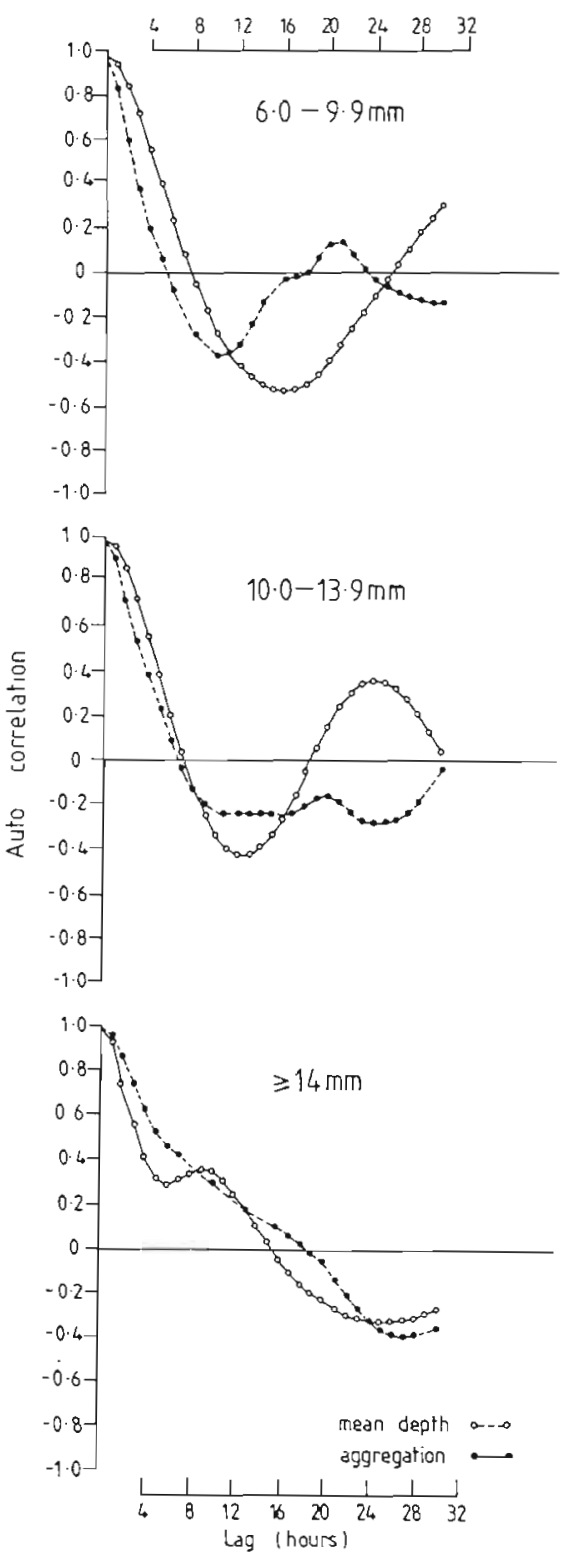

Fig. 7. Clupea harengus. Auto-correlation functions of aggregation and the depth of the centre of density (mean depth) for each size group of larvae sampled during the first drift survey (7 to 9 Sep)

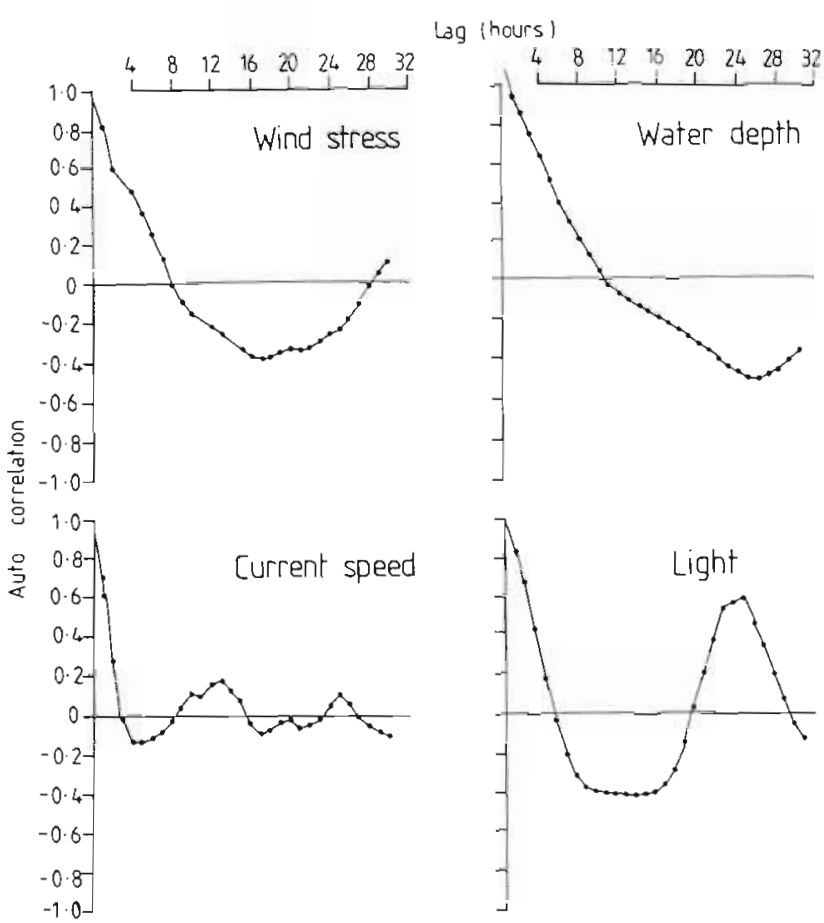

Fig. 8. Auto-correlation functions of each of the environmental parameters measured during the first drift survey ( $\beta$ to 9 Sep)

the depth-integrated population resides in each interquartile depth interval (Fig. 2).

The effects of wind mixing events on the distribution of larvae in the model are very marked. Fig. 14 shows examples of the predicted distributions of each size group of larvae in isothermal water at different light intensities and under different wind stress conditions. The model indicates that all the size groups of larvae are prevented from aggregating in response to light intensity when the wind stress is high.

The model successfully predicts that larvae of all size are restricted to the surface layer during daylight in stratified waters, but may descend below the base of the mixed layer at night (Fig. 15). In addition, the model indicates that during daylight in stratified water

Table 3. Clupea harengus. Coefficients of correlation between the auto-correlation functions for the aggregation and the depth of the centre of density (mean depth) aggregation of larvae, and the auto-correlation functions for the environmental parameters measured during the first drift survey period ( 7 to 9 Sep 1986). Size groups: $, 6.0-9.9 \mathrm{~mm}: \mathrm{M}, 10.0-13.9 \mathrm{~mm}, \mathrm{~L}, \geqslant 14.0 \mathrm{~mm}$

\begin{tabular}{|lccrrrr} 
& \multicolumn{3}{c}{ Aggregation } & & \multicolumn{2}{c}{ Mean depth } \\
& $\mathrm{S}$ & $\mathrm{M}$ & $\mathrm{L}$ & $\mathrm{S}$ & $\mathrm{M}$ & $\mathrm{L}$ \\
\hline Wind stress & 0.61 & 0.93 & 0.70 & 0.95 & 0.69 & 0.73 \\
Current speed & 0.45 & 0.45 & 0.39 & 0.27 & 0.22 & 0.50 \\
Water depth & 0.52 & 0.88 & 0.97 & 0.67 & 0.42 & 0.95 \\
Light intensity & 0.76 & 0.47 & -0.04 & 0.56 & 0.90 & -0.07 \\
\hline
\end{tabular}


Fig. 9. Clupea harengus. Cross-conelations of aggregation and depth of the centre of density (mean depth) of each size group of larvae at time (t) with environmental parameters measured at time $(t+\mathrm{lag})$ during the first drift survey ( 7 to 9 Sep)

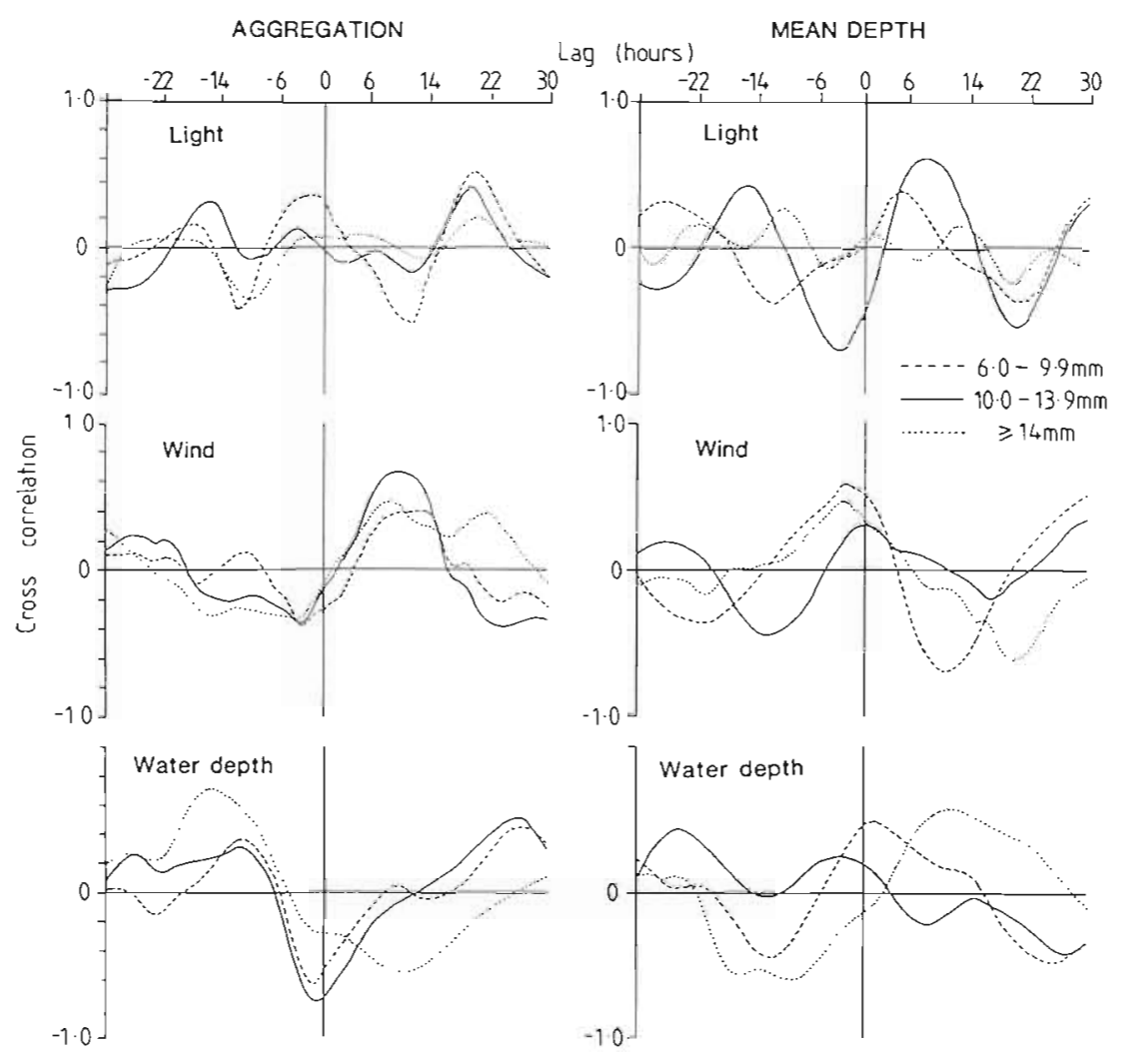

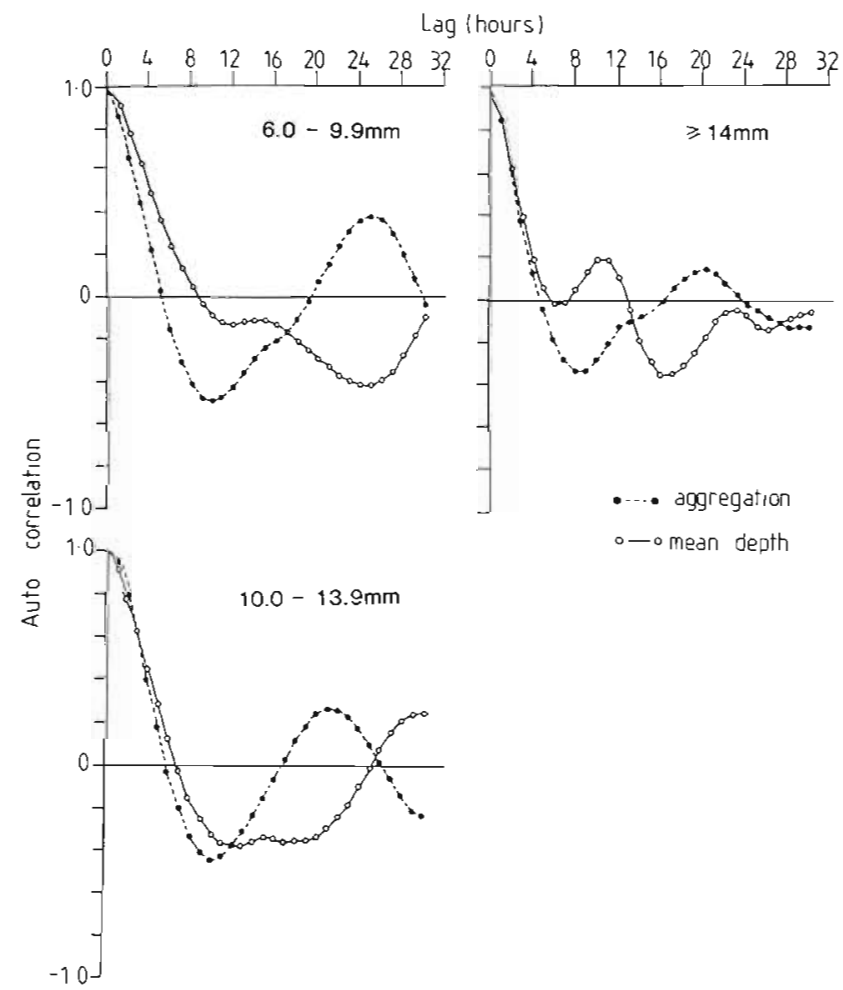

Fig. 10. Clupea harengus. Auto-correlation functions of aggregation and the depth of the centre of density (mean depth) for each size group of larvae sampled during the second drift survey (11 to $12 \mathrm{Sep}$ ) the small larvae aggregate closer to the surface than the larger larvae.

\section{DISCUSSION}

The qualitative assessment of most previous investigators has been that herring larvae exhibit phototaxis, and are confined to the upper layers in open-sea stratified environments. The quantitative results of this study generally concur with previous assessments in this respect. However, results indicate that larvae in the deeper layers of the water column show a greater phototactic response than larvae near the surface, so that the net effect of high surface irradiance is to cause aggregation or layering of the population rather than a major upwards migration of the centre of density. In addition, we have demonstrated the potential for wind mixing events to modify the vertical distribution of larvae. In all cases, high wind velocities cause dispersion of the population and downward displacement of the centre of density. It is not clear from these investigations whether this is an active response by the larvae to surface turbulence, or a passive mixing process. Comparison with other data not presented in this discussion, on the vertical distribution of copepod nauplii which are substantially less mobile than herring larvae, 


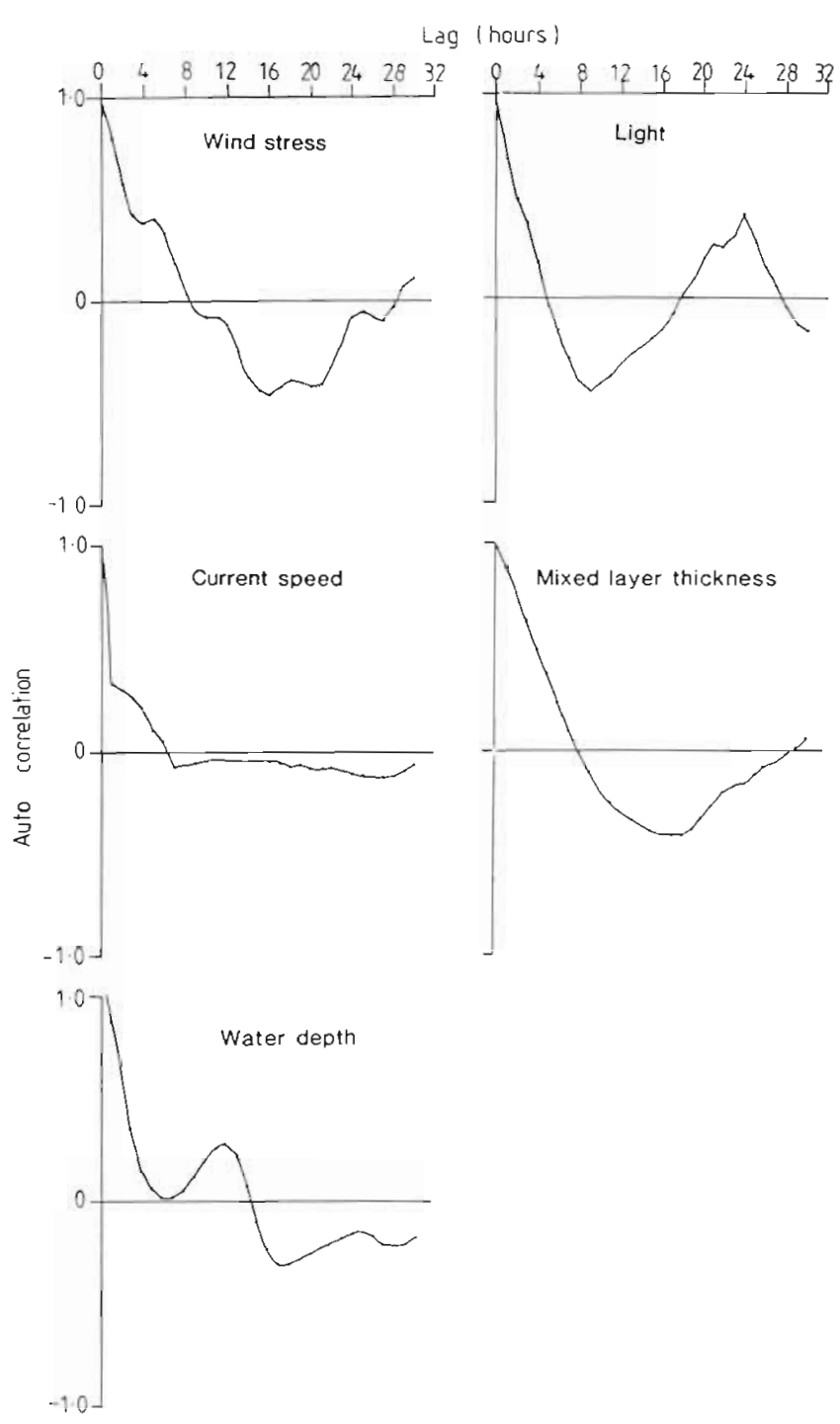

Fig. 11. Auto-correlation functions of each of the environmental parameters measured during the second drift survey (11 to $12 \mathrm{Sep}$ ) suggests that passive mixing cannot account for the large changes in the distribution of larvae during wind events. There is no clear discrimination between the mean depth of the centres of density of the 3 size groups of larvae examined. However, the model indicates differences in the reaction of the size groups to light and wind. In particular, larvae $\geqslant 14.0 \mathrm{~mm}$ showed least tendency to migrate in response to light, but a strong tendency to aggregate in mid-water in the isothermal environment and at the base of the mixed layer in stratified water. One factor not considered in this investigation, but which should be considered in future studies, is the possibility of an association between aggregations of prey items in the water column and the aggregation depth of larvae during periods when the light intensity threshold for visual feeding is exceeded.

There have been very few laboratory studies of vertical migratory behaviour in herring larvae. Woodhead \& Woodhead (1955) and Blaxter (1973) described the results of experiments on the effect of light intensity on vertical movement. Blaxter (1973) concluded that larvae tended to aggregate close to the surface at night. This result is contrary to the conclusions of the field studies reported here.

A criticism occasionally levelled at vertical distribution studies in the open sea is that a time of day-depth interaction with visual avoidance of the fishing gear by the larvae may distort the results. If this problem was so serious as to dominate the variability in catch rates then one would except the centre of density of the vertical distribution to move towards the surface at night. Clearly this is not the case in these studies, so although we cannot exclude the possibility of some influence, the results are obviously not dominated by such an effect.

The consequences of vertical distribution variability may be very significant for the advection of larvae. The concept of 'planktonic navigation' by vertical migration

Table 4. Clupea harengus. Coefficients of correlation between the auto-correlation functions for the aggregation and the depth of the centre of density (mean depth) aggregation of larvae, and the auto-correlation functions for the environmental parameters measured during the second drift survey period (11 to 12 Sep 1986). Size groups:, $6.0-9.9 \mathrm{~mm} ; \mathrm{m}, 10.0-13,9 \mathrm{~mm}, \mathrm{~L}, \geqslant 14.0 \mathrm{~mm}$.

\begin{tabular}{lcccccc} 
& \multicolumn{3}{c}{ Aggregation } & \multicolumn{2}{c}{ Mean depth } \\
& $\mathrm{S}$ & $\mathrm{M}$ & $\mathrm{L}$ & $\mathrm{S}$ & $\mathrm{M}$ \\
\hline Wind stress & 0.46 & 0.47 & 0.43 & 0.83 & 0.90 & 0.85 \\
Current speed & 0.45 & 0.70 & 0.74 & 0.96 & 0.76 & 0.79 \\
Water depth & 0.18 & 0.34 & 0.45 & 0.82 & 0.56 & 0.90 \\
Light intensity & 0.95 & 0.93 & 0.82 & 0.25 & 0.57 & 0.39 \\
Mixed layer depth & 0.60 & 0.64 & 0.59 & 0.87 & 0.96 & 0.84 \\
\hline
\end{tabular}



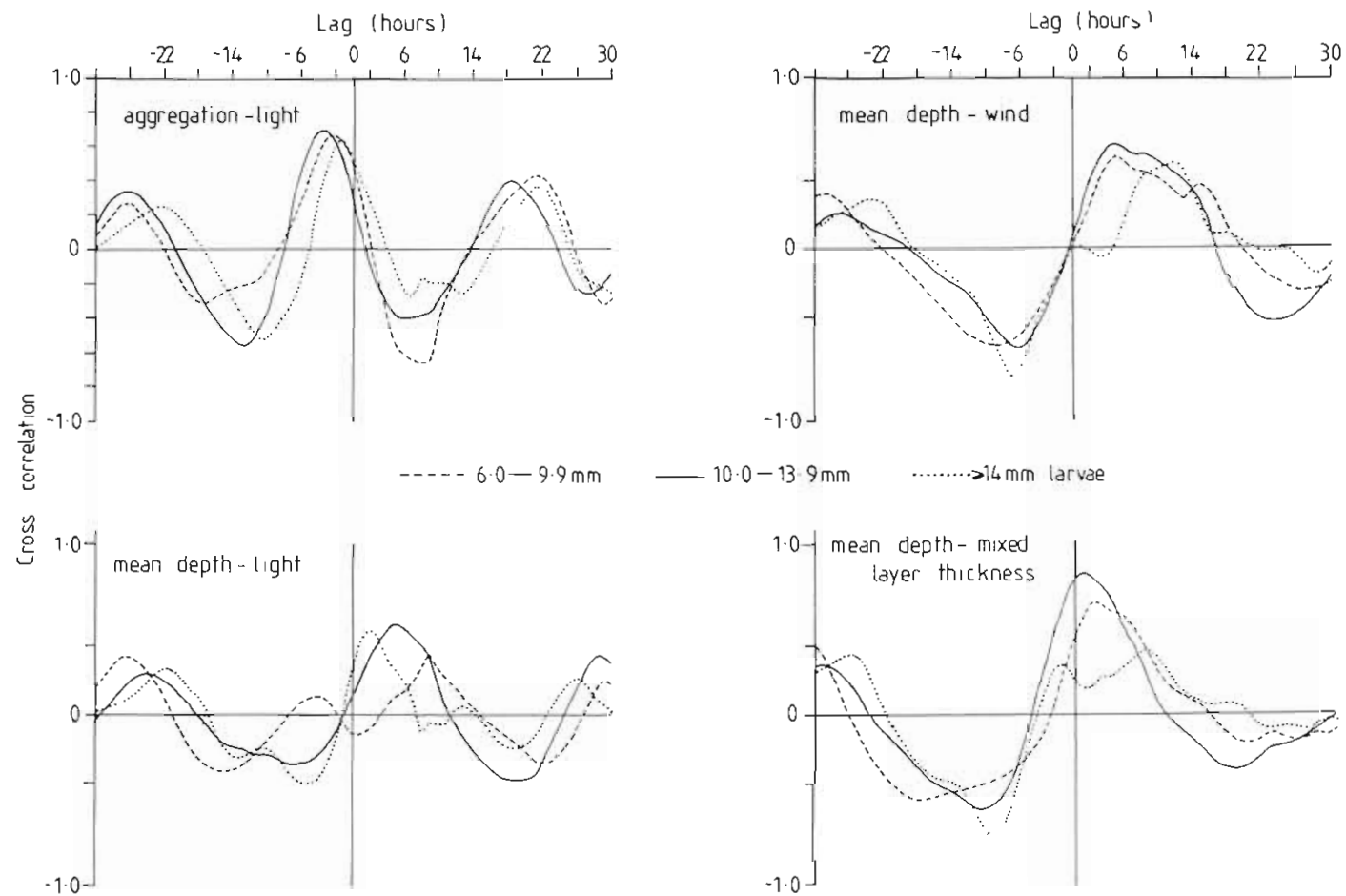

Fig. 12. Cluped harengus. Cross-correlations of aggregation and depth of the centre of density (mean depth) of each size group of larvae at time $(t)$ with environmental parameters measured at time $(t+\mathrm{lag})$ during the second drift survey (11 to 12 Sep)

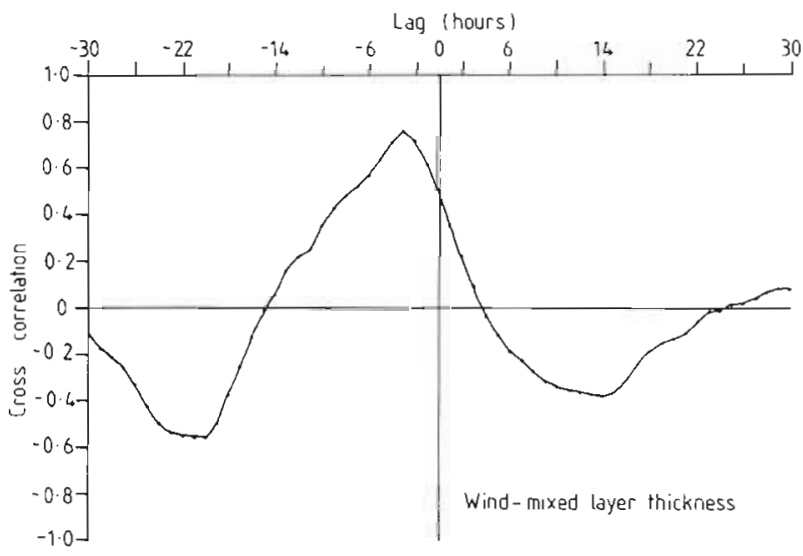

Fig. 13. Cross-correlation of wind stress at time $(t)$ with thickness of the mixed layer at time $(t+\mathrm{lag})$ during the second drift survey (11 to 12 Sep)

through a vertically heterogeneous velocity field has been recognised for many years (e.g. Mackintosh 1937). In the case of herring larvae, this phenomenon has been documented as a behavioural adaptation for position maintenance in rapidly flushing estuarine situations (Graham 1972, Fortier \& Leggett 1982). How- ever, the significance of this for larvae in the open sea is unclear. Iles \& Sinclair (1982) indicated that herring larvae are retained by the circulation on Georges Bank (NW Atlantic), and vertical migration could be a mechanism for achieving this, but off the north of Scotland larvae are clearly advected very rapidly through the area and indeed, are widely distributed in the North Sea some months later (Corten 1986, Heath \& Walker 1987). The strong interaction between vertical distribution and surface wind stress demonstrated here could be important in this context since the winter circulation in the North Sea is predominantly wind driven (Dooley 1974). In future we aim to refine our model of vertical migration and investigate a wider range of sizes of larvae. One of the objectives will be to use the model in conjunction with a 3-dimensional water circulation model to analyse the advection of larvae, in a manner similar to that described by Bartsch \& Backhaus (1987).

Acknowledgements. We are grateful to the officers and crew of FRV 'Scotia' for their help and cooperation in carrying out these studies, and to our scientific colleagues for their assistance at sea and in the laboratory. Particular thanks are due to J. Dunn and R. Mitchell for their work in developing the opening and closing net system. 
Table 5. Clupea harengus. Multiple regression coefficients for relations between quartile depths for each size group or larvae, and selected environmental parameters measured during the first drift survey period ( 7 to 9 Sep 1986). R-sq represents percentage of variance in the quartile depth data accounted for by the regressions

\begin{tabular}{|c|c|c|c|c|}
\hline \multirow[t]{2}{*}{ Independent variables } & \multicolumn{4}{|c|}{ Dependent variables (quartile depths) } \\
\hline & $D_{25 \%}$ & $\mathrm{D}_{50 \%}$ & $D_{75 \%}$ & $D_{100 \%}$ \\
\hline \multicolumn{5}{|l|}{ Larvae $6.0-9.9 \mathrm{~mm}$} \\
\hline Light intensity $\left(\mathrm{Wm}^{-2}\right)$ at time $(t-2) \mathrm{h}$ & 0.008 & -0.012 & -0.031 & -0.029 \\
\hline Wind stress $\left(\times 10^{-2} \mathrm{~Pa}\right)$ at time $(t-2) \mathrm{h}$ & 0.260 & 0.330 & 0.410 & 0.258 \\
\hline Water depth (m) & 0.920 & 1.120 & 1.200 & 1.110 \\
\hline Constant term: & -64.54 & -68.56 & -65.24 & -30.97 \\
\hline R-sq & 47.19 & 62.98 & 71.50 & 77.88 \\
\hline \multicolumn{5}{|l|}{ Larvae $10.0-13.9 \mathrm{~mm}$} \\
\hline Light intensity $\left(\mathrm{Wm}^{-2}\right)$ at time $(t-2) \mathrm{h}$ & -0.045 & -0.061 & -0.074 & -0.054 \\
\hline Wind stress $\left(\times 10^{-2} \mathrm{~Pa}\right)$ at time $(t-2) \mathrm{h}$ & 0.130 & 0.160 & 0.210 & 0.220 \\
\hline Water depth (m) & 0.460 & 0.600 & 0.880 & 1.200 \\
\hline Constant term: & -7.918 & -4.120 & -16.10 & -31.25 \\
\hline R-sq & 33.51 & 70.27 & 82.65 & 92.39 \\
\hline \multicolumn{5}{|l|}{ Larvae $>=14 \mathrm{~mm}$} \\
\hline Light intensity $\left(\mathrm{Wm}^{-2}\right)$ at time $(t-2) \mathrm{h}$ & -0.005 & -0.016 & -0.025 & -0.024 \\
\hline Wind stress $\left(\times 10^{-2} \mathrm{~Pa}\right)$ at time $(t-2) \mathrm{h}$ & 0.470 & 0.590 & 0.660 & 0.560 \\
\hline Water depth (m) & 0.230 & 0.530 & 0.820 & 1.210 \\
\hline Constant term: & -13.39 & -32.90 & -49.99 & -63.35 \\
\hline $\mathrm{R}-\mathrm{sq}$ & 45.45 & 34.85 & 28.98 & 22.42 \\
\hline
\end{tabular}

Table 6. Clupea harengus. Multiple regression coefficients for relations between quartile depths for each size group or larvae, and selected environmental parameters measured during the second drift survey period (11 to 12 Sep 1986). R-sq represents percentage of variance in the quartile depth data accounted for by the regressions

\begin{tabular}{|c|c|c|c|c|}
\hline \multirow[t]{2}{*}{ Independent variables } & \multicolumn{4}{|c|}{ Dependent variables (quartile depths) } \\
\hline & $\mathrm{D}_{25 \%}$ & $\mathrm{D}_{50 \%}$ & $\mathrm{D}_{7,5 \%}$ & $\mathrm{D}_{100 \%}$ \\
\hline \multicolumn{5}{|l|}{ Larvae $6.0-9.9 \mathrm{~mm}$} \\
\hline Light intensity $\left(\mathrm{Wm}^{-2}\right)$ at time $(t-2) \mathrm{h}$ & -0.018 & -0.056 & -0.096 & -0.164 \\
\hline Mixed layer depth $(m)$ & 0.550 & 0.660 & 0.550 & 0.240 \\
\hline Constant term. & -13.21 & -5.576 & 18.34 & 70.59 \\
\hline $\mathrm{R}$-sq & 29.28 & 43.46 & 48.13 & 54.73 \\
\hline \multicolumn{5}{|l|}{ Larvae $10.0-13.9 \mathrm{~mm}$} \\
\hline Light intensity $\left(\mathrm{Wm}^{-2}\right)$ at time $(t-2) \mathrm{h}$ & $\begin{array}{r}-0.022 \\
0.570\end{array}$ & $\begin{array}{r}-0.046 \\
0.640\end{array}$ & $\begin{array}{r}-0.068 \\
0.610\end{array}$ & $\begin{array}{r}-0.139 \\
0.760\end{array}$ \\
\hline Constant term: & -8.612 & 1.593 & 18.26 & 44.73 \\
\hline $\mathrm{R}$-sq & 36.02 & 49.84 & 57.72 & 65.24 \\
\hline \multicolumn{5}{|l|}{ Larvae $\geqslant 14 \mathrm{~mm}$} \\
\hline Light intensity $\left(\mathrm{Wm}^{-2}\right)$ at time $(t-2) \mathrm{h}$ & 0.013 & -0.043 & -0.068 & -0.105 \\
\hline Mixed layer depth (m) & -0.270 & -0.410 & -0.320 & -0.270 \\
\hline Constant term: & 42.48 & 67.32 & 75.47 & 99.06 \\
\hline R-sq & 5.71 & 16.14 & 18.14 & 28.57 \\
\hline
\end{tabular}




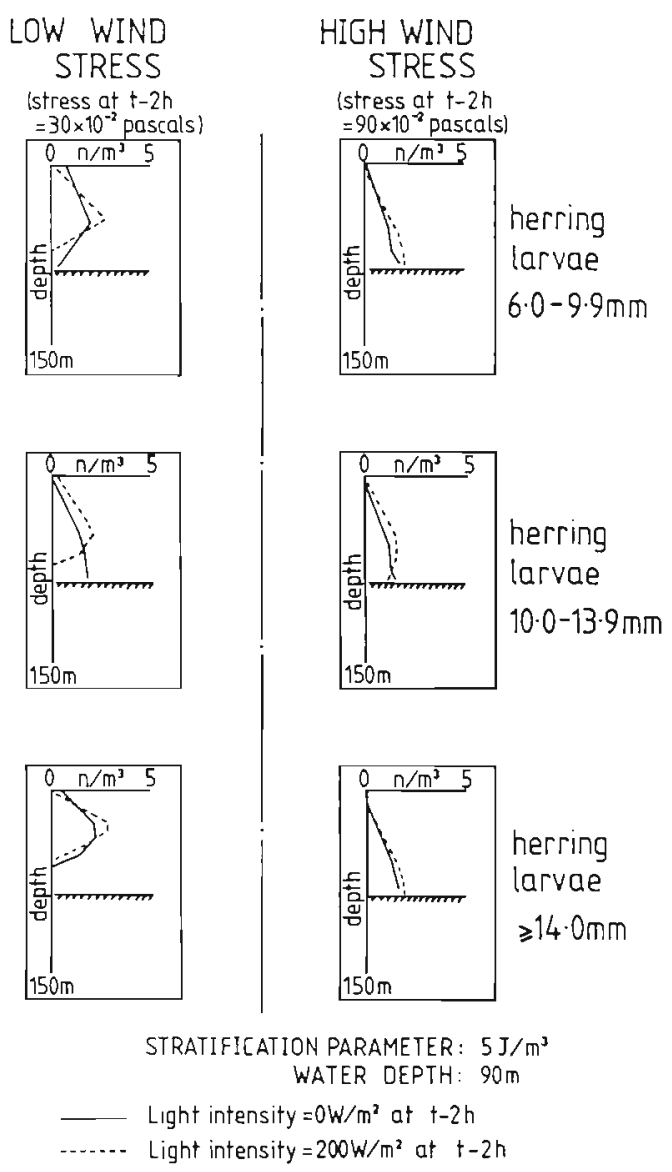

Fig. 14. Clupea harengus. Simulations of the vertical distributions of 3 size groups of herring larvae in a $90 \mathrm{~m}$ isothermal water column, with low and high surface wind stress $\left(30 \times 10^{-2}\right.$ and $\left.90 \times 10^{-2} \mathrm{~Pa}\right)$ and in darkness and at approximately midday light intensity of the sea surface $\left(200 \mathrm{Wm}^{-2}\right)$

\section{LITERATURE CITED}

Bartsch, J., Backhaus, J. (1987). Numerical simulation of the advection of vertically/migrating herring larvae in the North Sea. Coun. Meet. int. Coun. Explor. Sea C.M.-ICES/ C:53 Hydrography Committee (mimeo)

Bjorke, H., Fossum, P., Saetre, R. (1986). Distribution, drift and condition of herring larvae off western Norway in 1985 Coun. Meet. int Coun. Explor. Sea C.M.-ICES/H:39 Pelagic Fish Committee (mimeo)

Blaxter, J. H. S. (1973). Monitoring the vertical movements and light responses of herring and plaice larvae. J. mar. biol. Ass. U. K. 53: 635-647

Brander, K., Nichols, J. and Thompson, A. (1987). A study of avoidance of sampling gear by herring larvae. Coun. Meet. int. Coun. Explor. Sea C.M.-ICES/L:18 Biological Oceanography Committee (mimeo)

Bridger, J. P. (1958). On efficiency tests made with a modified Gulf III High-Speed Tow Net. J. Cons. perm. int. Explor. Mer 23: 357-365

Corten, A. (1986). On the causes of recruitment failure of herring in the central and northern North Sea in the years 1972-1978. J. Cons. int. Explor Mer 42: 281-294

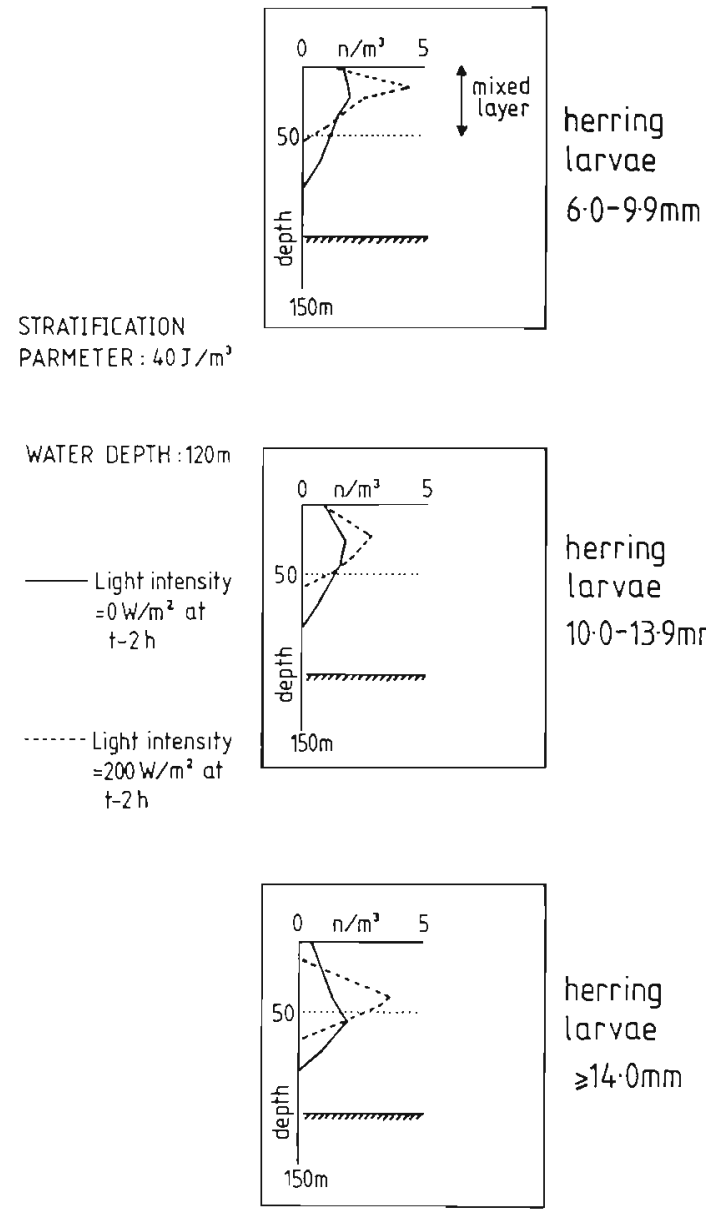

Fig. 15. Clupea harengus. Simulations of the vertical distributions of 3 size groups of herring larvae in a $120 \mathrm{~m}$ stratified water column with a mixed layer thickness of $50 \mathrm{~m}$, in darkness and at approximately midday light intensity at the sea surface $\left(200 \mathrm{Wm}^{-2}\right)$

Dooley, H. D. (1974). Hypotheses concerning the circulation of the northern North Sea. J. Cons. perm. int. Explor. Mer 36 $54-61$

Dragesund, O. (1970). Factors influencing year-class strength of Norwegian spring spawning herring. Fisk. Dir. Skr. Ser. Havunders. 15: 381-450

Dunn, J., Mitchell, R. B., Ritchie, B. J. (1985). A new multidepth high speed plankton sampler, Coun. Meet. int. Coun. Explor. Sea C.M.-ICES/L:7 Biological Oceanography Committee (mimeo)

Fortier, L., Leqgett, W. C. (1982). Fickian transport and the dispersal of fish larvae in estuaries. Can. J. Fish. Aquat. Sci. 39: 1150-1163

Fortier, L. and Leggett, W. C. (1983). Vertical migrations and transport of larval fish in a partially mixed estuary. Can. J. Fish. Aquat. Sci. 41: 1543-1555

Gehringer, J. W. (1952). An all metal plankton sampler (model Gulf III). Spec. scient. Rep. U. S. Fish. Wildl. Serv. 88: 7-12

Graham, J. J. (1972). Retention of larval herring within the Sheepscot estuary of Maine. Fish. Bull. (U. S. 70: 299-305

Graham, J. J., Sampson, D. B. (1982). An experiment on factors affecting depth distribution of larval herring, Clupea harengus, in coastal Maine. NAFO Sci. Coun Studies 3: 33-38 
Heath, M. R., Walker, J. (1987). A preliminary study of the drift of larval herring (Clupea harengus L.) using gene frequency data. J. Cons int. Explor Mer 43: 139-145

Iles, T D., Sinclair, M. (1982). Atlantic herring: stock discreteness and abundance. Science 215: 627-633

Jenkins, G. M., Watts, D. G. (1968). Spectral analysis and its applications. Holden-Day, San Francisco

Mackintosh, N. A. (1937). The seasonal circulation of the Antarctic macroplankton. Discovery Rep. 16: 367-412

McLellan, H. J. (1965). Elements of physical oceanography Pergamon Press, Oxford

Nichols, J. H., Thompson, B. M., Riley, J. D. (1986). Herring larvae studies in the west central North Sea in 1985. Coun. Meet. int. Coun. Explor. Sea C.M.-ICES/H:23 Pelagic Fish Committee (mimeo)

Richardson, K., Heath, M. R., Pihl, N. J. (1986). Studies of a larval herring (Clupea harengus L.) patch in the Buchan area. I. The distribution of larvae in relation to hydrographic features. Dana 6: 1--10

Schnack, D. (1972). Nahrungsokologische Untersuchungen an
Heringslarven. Ber. dt. wiss. Kommn Meeresforsch. 22: 273-343

Seliverstov, A. S. (1974). Vertical migrations of larvae of the Atlanto-Scandian herring (Clupea harengus L.). In: Blaxter, J. H. S. (ed.) The early life history of fish. SpringerVerlag, New York, p. 253-261

Simpson, J. H. (1981). The shelf-sea fronts: implications of their existence and behaviour. Phil. Trans. R. Soc. Lond A. 302: $531-546$

Simpson, J. H., Hunter, J. (1974). Fronts in the Irish Sea. Nature, Lond. 250: 404-406

Wiebe, P. H., Burt, K. H., Boyd, S. H., Morton, A. W. (1976). A multiple opening/closing net and environmental sensing system for sampling zooplankton. J. mar Res. 34: 313-326

Woodhead, P. M. J., Woodhead, A. D. (1955). Reactions of herring larvae to light: a mechanism of vertical migration. Nature, Lond. 176: 349-350

Wood, R. J. (1971). Some observations on the vertical distribution of herring larvae. Rapp. P.-v. Réun. Cons. int. Explor Mer 160: 60-64

This article was submitted to the editor; it was accepted for printing on June 6,1988 